\author{
Published by Avanti Publishers
}

The Global Environmental

Engineers

ISSN (online): 2410-3624

\title{
Review of Wastewater Treatment Technologies in View of their Application in the DR Congo Mining Industry
}

\author{
Michel Shengo Lutandula* and Fabien Ilunga Mpanga \\ Department of Chemistry, Inorganic Chemistry Unit, Faculty of the Sciences, University of Lubumbashi, P.O. Box 1825, Likasi \\ Avenue, City of Lubumbashi, Haut-Katanga Province, Democratic Republic of the Congo
}

\begin{abstract}
ARTICLE INFO
Article Type: Review Article

Keywords:

Water crisis

Wastewaters

Improved water access

Treatment technologies

Water ever-growing demand

Timeline:

Received: September 05, 2021

Accepted: October 11, 2021

Published: October 29, 2021

Citation: Lutandula MS, Mpanga Fl. Review of Wastewater Treatment Technologies in View their Application in the DR Congo Mining Industry. Glob. Environ. Eng. 2021; 8: 14-26.
\end{abstract}

DOl: https://doi.org/10.15377/2410-3624.2021.08.2

\begin{abstract}
The world is currently facing the water crisis brought about by the deterioration in its quality and the difficult access to its resources due to ever-growing demand in largescale consumer sectors such as agriculture, industry and tourism. Consequently, increasing pressure on water resources is experienced in the world as the outcome of the strong population growth, continued urbanization and rapid industrialization, together with numerous discharges of polluted waters into watercourses. Strategies have been developed throughout the world for improving both the quality and access to water in a sufficient quantity. Thus, different technologies, both established and emerging ones, are presently utilized in view to treat wastewaters, including those of the mining origin. The present work reviews the different uses of water in the mining industry and identifies different sources of polluted waters. It analyses wastewater treatment techniques in view of their application specifically to the treatment of wastewaters from the DR Congo mining industry. As such, this work identifies itself as part of an effort to contribute to the improvement of wastewater management practices in the DR Congo mining industry as well as improved access and sustainable use of water resources.
\end{abstract}

*Corresponding Author Email: shengolutandulamichel@yahoo.fr Tel: +243842186336/ +243995084289

(c) 2021 Lutandula and Mpanga. Published by Avanti Publishers. This is an open access article licensed under the terms of the Creative Commons Attribution Non-Commercial License which permits unrestricted, non-commercial use, distribution and reproduction in any medium, provided the work is properly cited. (http://creativecommons.org/licenses/by-nc/4.0/) 


\section{Introduction}

Fresh water is a scarce natural resource very essential to life and any productive activity [1-9]. Water worldwide availability or accessibility (Figure 1) is not uniform [10] given that some regions have significant water resources, while others, such as in the Northern region of China [11], Chile and the WANA region endure water scarcity and drought $[2,6,10-14]$. The WANA region includes countries in North Africa (Algeria, Morocco, Tunisia, Libya, Egypt, Eritrea, Ethiopia, and Sudan), West Asia (Turkey, Cyprus, Iraq, Jordan, Lebanon, and Syria) as well as all the Middle Eastern countries in the Arabian Peninsula and Iran.

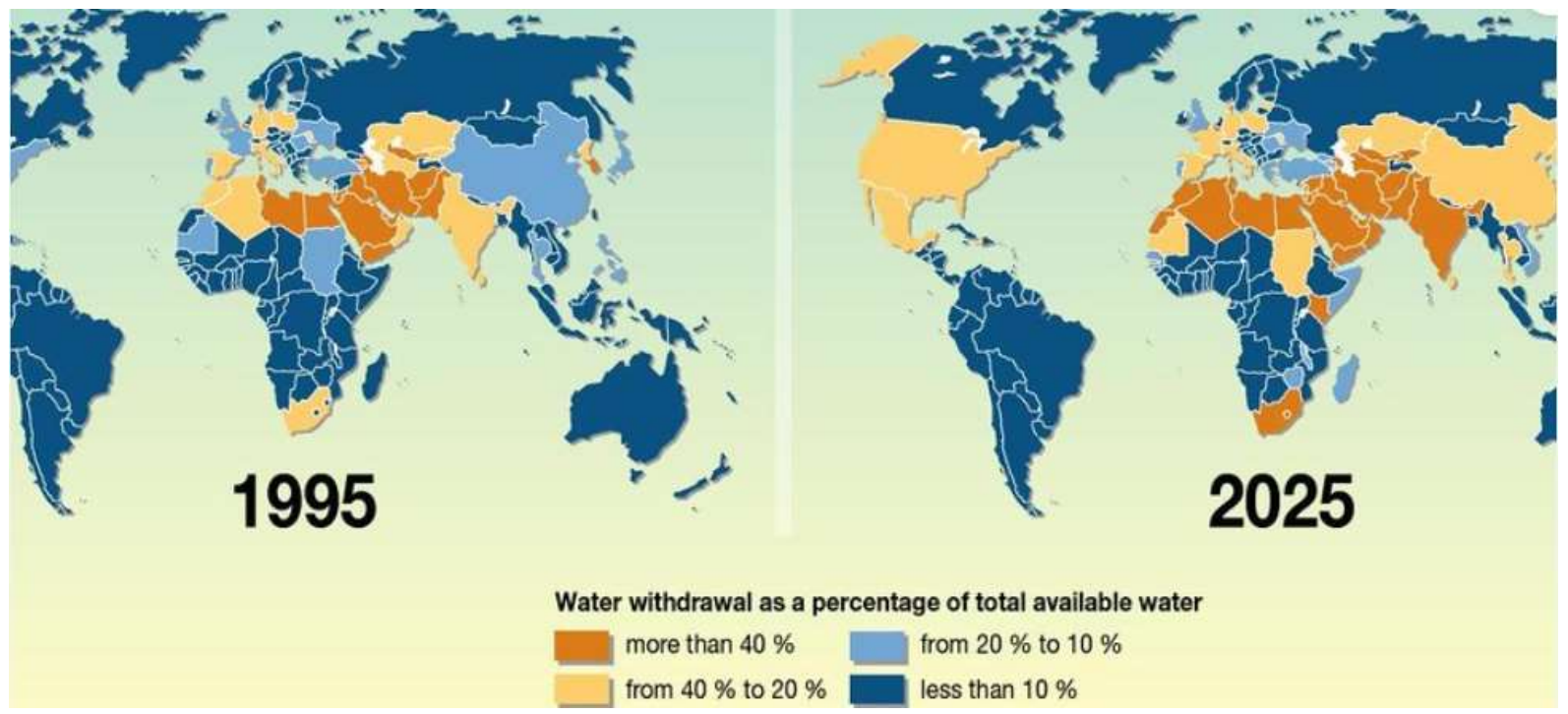

Figure 1: Water withdrawal as a function of total water available.

About 1.2 billion people do not have access to water around the world [6]. While sustainable development advocates access to good water and in sufficient amount for all [15, 16], 2.4 to 2.6 billion people are deprived of this vital resource [2]. Consequently, those people do not enjoy a minimum of health conditions and die from waterborne diseases $[2,17,18]$. This situation has affected more than $66 \%$ of the Asian population [19] of which the majority belongs to the WANA region, which accounts for a major proportion of the world's driest areas [2].

The world is currently experiencing a water crisis from the point of view of both quality deterioration and the lack of access to sufficient quantity $[2,18]$. According to [16], Water scarcity means the lack of sufficient water, or not having access to safe water supplies and this concept is clearly different from water stress. This refers to a lack to meet human and ecological demand for water during a certain period; a situation experienced by a large proportion of the world's population [20]. Indeed, there is increasing pressure on water resources induced by population strong growth and continuous urbanization, rapid industrialization as well as the intensification of food production $[6,8,10,21]$. Another issue to be mentioned, in relationship with the water crisis, is the increasing number of discharges into waterways of polluted waters $[4,5,22-25]$ in the majority of countries $[2,18]$. The water crisis has resulted in over-exploitation of aquifers, rampant pollution of the environment [26] and shortages that have alienated the universal human right to have good quality water in sufficient quantity at one's disposal $[2,5,9$, 17].

[9] argue that the adoption of water recycling practices, implementation of wastewater treatment processes and use of remediation systems has become inescapable routes for increasing access to water [6, 27]. Thus, strategies have been developed throughout the world in view of improving access to water [6]. Different technologies, both established and emerging ones, are utilized in view to treat raw water and to produce safe water [9]. These technologies are utilized for treating wastewaters of different origins, including those from the mining industry and enable recovering safe water that is either used in other sectors or released to watercourse $[1,12,28-39]$. 
In 2003, for instance, global wastewater production was estimated at approximately 1,500 km3 [40]. In emerging countries such as China [41], the volume of wastewater of the mining origin was estimated at 1,028 mega tonnes, an amount that accounted for about $6 \%$ of the total volume of industrial wastewater (Table 1).

Table 1: Industrial wastewater production in China

\begin{tabular}{|c|c|c|c|c|}
\hline Industrial Sector & Number of Enterprises & $\begin{array}{c}\text { Total Volume } \\
\text { (Mega Tonne) }\end{array}$ & $\begin{array}{c}\text { Standard Volume } \\
\text { (Mega Tonne) }\end{array}$ & 2,257 \\
\hline \hline Food and brewing & 11,672 & 2,546 & 3,040 & 11.0 \\
\hline Chemical & 9,326 & 3,240 & 367 & 14.8 \\
\hline NFS Manufacturing & 21,402 & 403 & 316 & 1.8 \\
\hline Metal manufacturing & 5,995 & 333 & 1,825 & 1.5 \\
\hline Foundry & 2,408 & 318 & 533 & 8.5 \\
\hline Metallurgical & 6,086 & 1,887 & 3,038 & 3.0 \\
\hline Mining & 2,314 & 594 & 404 & 18.7 \\
\hline Paper & 5,818 & 4,246 & 429 & 2,047 \\
\hline Pharmaceutical & 2,605 & 2,252 & 384 & 10.0 \\
\hline Textile & 7,644 & 434 & 22,076 & 1.9 \\
\hline NFM processing & 1604 & 106,434 & & 100 \\
\hline
\end{tabular}

NFM: non ferrous metal, SNF: Non ferrous substances.

Regarding the management of mine wastewater in Europe, statistics reveal that in Germany, for instance, about $12 \%$ of the total volume is handled. Surface water receives 5,750 million $\mathrm{m}^{3}$ of wastewater. Industrial wastewater treatment is recommended owing to its high pollution capacity $[42,43]$. Indeed, the mismanagement of one litre of wastewater can result in the pollution of 8 litres of fresh water [40]. Mining wastewater treatment is done using different physical, chemical or biological technologies $[22,44]$. The treatment of wastewater consists of a combination of physical, chemical and/or biological processes and operations enabling the removal of contaminants, including colloids, organic and inorganic matters, nutrients as well as soluble matters (metals, organics, etc.) [5, 26, 45-47].

The present work reviews the different uses of water in the mining industry and identifies different sources of polluted water. It analyses wastewater treatment techniques in view of their application specifically to the treatment of wastewaters from the DR Congo mining industry. As such, this work is part of an effort to contribute to the improvement of wastewater management practices in the DR Congo mining industry as well as improved access and sustainable use of water resources.

\section{Water Uses in the Mining Industry}

Water is vital for any industrial activity $[18,48]$ because it is used as a solvent, as the main ingredient of industrial processes, as a reagent, as cleaning liquid, as reaction and transport medium and as a medium for reactants, as heat exchange fluid or as a source of electrical energy [49-51]. With about $25 \%$ of global demand for water, industry ranks second only to agriculture in terms of water consumption [18,50].

Water availability is thus one of the key variables in the design and materialization of a mining project [48]. Indeed, water is used at all stages (Figure 2) of a mine's life, that is, during the exploration phase of the ore deposits as well as during the mining and processing of ores. Water is used in dust suppression, worker camp supply, irrigation of surrounding lands and rehabilitation of mine sites [52]. 

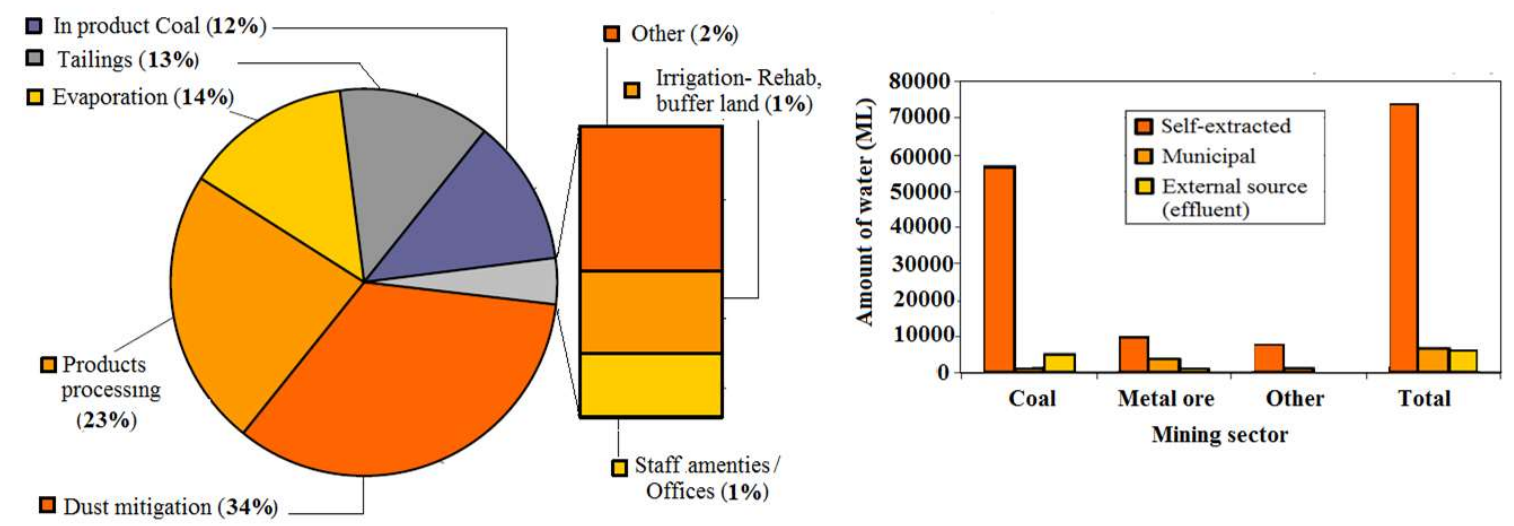

Figure 2: Water use at a mine in Queensland [15].

Table 2 below describes water consumption at some base metal mines in Australia [53].

Table 2: Water consumption in some Queensland mines

\begin{tabular}{|c|c|c|c|}
\hline Mine & Mined Ore & $\begin{array}{c}\text { Daily Water Consumption } \\
\text { (Mega Litre) }\end{array}$ & $\begin{array}{c}\text { Annual Water Consumption } \\
\text { (Mega Litre) }\end{array}$ \\
\hline \hline A & Copper-gold & $13-17.8$ & $4,750-6,500$ \\
\hline B & Lead-Zinc-Silver & 6 & 2,200 \\
\hline C & Copper-gold & 5.2 & 2,000 \\
\hline D & Copper-gold & 1.2 & 450 \\
\hline E & Lead-Zinc-Silver & $26-52$ & $9,500-19,000$ \\
\hline
\end{tabular}

For instance, from the mining of ore until the extraction process of copper as metal, water is used in the achievement of operations described in Figure 3.

\subsection{Water Supply to the Workers' Camp}

The proportion of water intended for feeding a mining camp, particularly for the usual domestic needs and environmental sanitation, is by far negligible compared to that requested by mining operations.

\subsection{Water Used in Mining Operations}

The proportion of water consumed by mining operations is estimated at about $15 \%$ of the total water volume consumed at a mine site. The largest water consumption at an open-pit mine site is due to dust suppression. It depends on the morphology of the terrain and varies according to the seasons and in arid areas, it may be more important [12]. For mining sites located in regions with high rainfall, dust suppression is carried out naturally resulting in lowering of the overall amount of consumed water.

In an underground mine, the proportion of water required for dust suppression is small [12]. Depending on the conditions of a mine site, that proportion varies between 0 and 15\% of the total volume of water used for all mining operations. This water comes from the pumping of groundwater or from the collection of runoff waters $[12,54]$.

\subsection{Water Supply to an Ore Concentrator}

It represents the largest volume of water consumed at a mine site [12, 54]. Indeed, grinding and beneficiation of ores through flotation or gravity separation usually consumes large volumes of water. Copper ores, for 
instance, can be mined as sulphides or oxides and their beneficiation through flotation is the most waterconsuming operation given that it is conducted using pulps (Figure 4) containing 25 to $45 \%$ of solids [12].

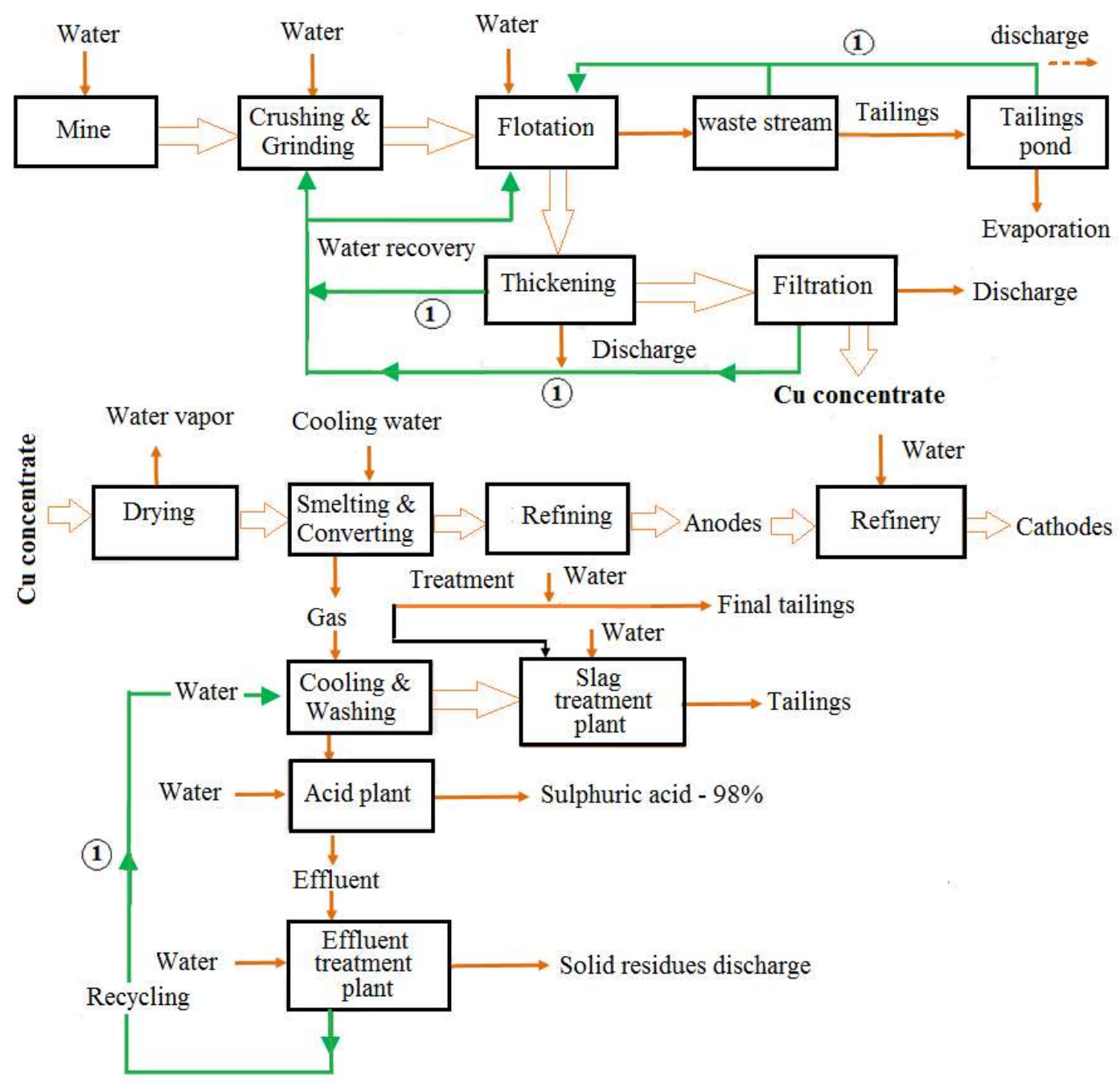

(1) Water recycling in the process

Figure 3: Water consumption during the pyrometallurgical production of copper (modified from [12]).

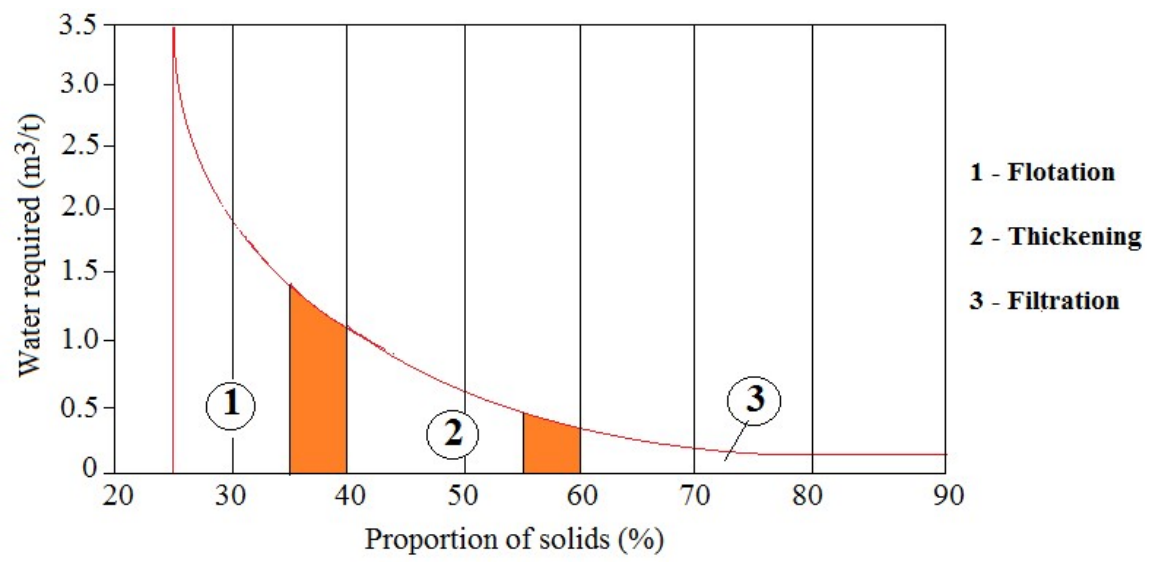

Figure 4: Water consumption during the flotation beneficiation of copper ores (After [12]). 
Flotation is reputed a water-consuming mineral processing operation that enables economically separating valuable minerals from the gangue ones $[33,55]$. Water flow rates in the range of 300 to $500 \mathrm{~m}^{3} / \mathrm{h}$ are utilized in the flotation of copper-cobalt oxidized ores mined in the Katanga region of the DR Congo [56, 57]. The variation in the proportion of solids in the pulp (Figure 4) is revealing that most of the feed water (80-90\%) finds one's in the discharges from the ore flotation. Settling and filtration operations of the final concentrate enable recovering wastewater from the flotation of ores $[12,56]$, with the recovered wastewater either mixed with flotation tailings or returned to the process $[12,32,33]$.

In copper ores flotation, for instance, water consumption ranges from 1.5 to $3 \mathrm{~m}^{3 / \mathrm{t}}[12,54]$. Milling and flotation of $\mathrm{Pb}-\mathrm{Zn}$ polymetallic ores require water flow rates in the order of $6000 \mathrm{~L} / \mathrm{h}$ [58]. As for the production of one tonne of metallic copper, for instance, it requires approximately $13.6 \mathrm{~m}^{3}$ of water, that is, from the mining of ores until their flotation beneficiation.

The water consumption of a concentrator is estimated at $0.75 \mathrm{~m}^{3}$ per tonne of ore. Maximizing recycling and prevention of water leakage, together with losses due to evaporation, can help optimize water consumption up to $0.34 \mathrm{~m}^{3}$ per tonne of ore, as is the case in some ore concentrators operated in Chile and Australia [54]. The life cycle analysis showed that water consumption in terms of tonnes for the production of various base metals ranges from 3 to $250 \mathrm{~m}^{3}$. Its extreme values have been observed in gold and steel manufacturing [59].

Table 3 illustrates the water consumption during the production of some base metals, that is, from the mine until the ores beneficiation through flotation.

Table 3: Water consumption from the mine to the base metal

\begin{tabular}{|c|c|}
\hline Metal & Water Consumption $\left(\mathbf{m}^{3}\right.$ Per Tonne) \\
\hline \hline Copper & 7.8 \\
\hline Nickel & 0.93 \\
\hline Lead & 0.64 \\
\hline Zinc & 0.64 \\
\hline Iron/Steel & 0.21 \\
\hline Titanium & 5.15 \\
\hline Aluminium & 0.3 \\
\hline
\end{tabular}

\subsection{Water Used to Transfer Ores and Concentrates}

During ores processing, minerals are moved through pipes in the form of pulps from one machine to another [48]. The same applies to concentrates when they have to pass from one enrichment stage to another or be sent to the thickening and to dehydration by vacuum filtration in view obtaining a cake with the moisture in the range 10 to $15 \%$, that is, the final concentrate.

Some concentrators are designed so that the wet grinding section is situated away from the ores flotation section. This implies transferring from one processing section to another of large tonnages of solid materials in the form of pulps. Sometimes the settling and filtration sections of the final concentrate are located in a seaport in view facilitating the export of the concentrates to an electrical smelter. This is the case at the Escondida mine or to that of the Pelambres located in Chile [12]. The proportion of water dedicated to this operation accounts for 4 to $6 \%$ of the total volume consumed by an ores concentrator. The Alumbrera Mine (Argentina) possesses the longest pipeline $(316 \mathrm{~km})$ in the world for transferring ores concentrates (Cu-Ag) until to the settling and filtration plant using water pumping [60]. 


\subsection{Water Supply to a Foundry Cooling System}

In an electrical foundry, for instance, the production of copper blister or copper anodes is done using the smelting-conversion process conducted inside specialized metallurgical reactors [12]. The feed is often composed of dry sulphide concentrates containing $0.2 \%$ humidity. Their metallurgical conversion into mattes requires oxygen of which the production consumes large amounts of water [12]. An amount of $7.8 \mathrm{~m}^{3}$ of water is required for the smelting process in view of obtaining one tonne of copper metal and an additional $0.6 \mathrm{~m}^{3}$ of water is required for refining operations of the obtained metal [59].

In an electric foundry, water is also utilized as a coolant for furnaces, in the granulation process of slag and metal alloys as well as during the cleaning of the smelting furnace exhaust gases. This is the reason why several smelters are located near the watercourses [56]. Indeed, they collect their feed water upstream and discharge the wastewater downstream in rivers used as spillways [57, 61]. The Big Hill Smelter in Lubumbashi (the "Société du Terril de Lubumbashi" in French), operated in Katanga region since 2002 up to 2017 and again until nowadays, illustrates this practice with the Lubumbashi River used as the source of the electric arc furnace cooling water and as a spillway of the process wastewater. This smelter had produced copper and cobalt alloys through reprocessing of slag from the pyrometallurgy extraction of copper [61], with the cooling system consuming 70-75 $\mathrm{m}^{3}$ of water per hour abstracted from the Lubumbashi River. In Chile, studies have shown that electric smelters of copper consume on average $3.6 \mathrm{~m}^{3}$ of water per tonne of metal for the functioning of their cooling systems [12].

\subsection{Water Supply to a Metal Refining Plant}

Metal anodes of copper produced by an electric foundry are refined through electrolysis $\left(60^{\circ} \mathrm{C}\right)$ in view removing impurities so that their concentrations become as low as 0.1-0.3\% [12]. During metal refining, water consumption is due to evaporation losses as well as, the bleeding of electrolytes loaded with impurities ( $\mathrm{As}, \mathrm{Sb}, \mathrm{Cl}$, etc.) in view of diminishing their concentrations in the processing circuit [62].

\section{Sources of Wastewater of Mining Origin}

Throughout their lives, mines discharge to the environment various types of wastewater [24, 63], that is, since the exploration stage of ore deposits until the extraction of metals of interest. The released wastewater contains a variety of pollutants $[24,33,63,64]$ responsible for the deterioration of the quality of groundwater and surface water (Table 4).

Major sources of wastewater of mining origin are described below:

\subsection{Acid Mine Drainage (AMD)}

The main source of polluted waters in relationship with mining activities is acid mine drainage (AMD) [11, 44, 65- 68]. The AMD is an acid-generating process that occurs following exposure to air and water of reactive sulphides such as flotation tailings or mining wastes $[65,66,68,69]$. It is the biggest environmental issue mining companies are confronted with, especially during the rehabilitation of abandoned mine sites or after closure [65$67,70]$.

In 1989, it had been reported that about 19,300 km of rivers, 72,000 ha of lakes and water reserves were negatively impacted by liquid effluents from the mining industry [67]. According to [66], AMD acidifies the receiving environment through the liberation of sulphuric acid, and the maintaining in aqueous solutions of highly reactive and toxic metals $[65,68]$. Indeed, it is difficult to stop an AMD and it cannot do it on its own. The generation of persistent acids observed in mining areas, around 1700 in Norway, is perfectly illustrating this phenomenon [67, 71]. In addition, the costs of containment of pollution due to AMD are such that they can swallow up over the long term the economic gain from an initially profitable mining operation. Indeed, the neutralization of water polluted by an AMD at the abandoned site of mine Equity (Houston-British Columbia), for instance, costs annually more than 1.2 million USD to the mining company. This acid generation process is expected to continue for 150,000 years [71]. 
Table 4: Physicochemical quality of liquid effluents from ore flotation

\begin{tabular}{|c|c|c|}
\hline Parameter (Unit) & Unfiltered Liquid Effluent & Liquid Effluent from a DRC Concentrator \\
\hline $\mathrm{pH}$ & 8.0 & 10.11 \\
\hline Turbidity (NTU) & 7.5 & NA \\
\hline Electric conductivity $(\mu \mathrm{S} / \mathrm{cm})$ & 171 & 4,290 \\
\hline Colour (TCU) & NA & 550 \\
\hline Saltiness & NA & 1.9 \\
\hline Matter in suspension (mg/L) & NA & 674 \\
\hline Copper (mg/L) & 0.03 & 0.38 \\
\hline Cobalt (mg/L) & NA & 0.24 \\
\hline Manganese (mg/L) & NA & 0.40 \\
\hline Zinc (mg/L) & 0.32 & NA \\
\hline Lead (mg/L) & 0.013 & 0.09 \\
\hline Nickel (mg/L) & NA & 0.03 \\
\hline Arsenic (mg/L) & 0.011 & NA \\
\hline Iron (mg/L) & 0.23 & 0.34 \\
\hline Cadmium (mg/L) & 0.008 & 0.01 \\
\hline Mercury (ppb) & 0.66 & NA \\
\hline Sulphate ions (mg/L) & NA & 364 \\
\hline
\end{tabular}

NA: not available

Acid generation is a process that therefore appears under certain natural conditions. Its exacerbation is due to mining activities, that is, the excavation and milling of sulphide minerals and their exposure to air and water outside their natural environment $[65,66]$. The magnitude of AMD is determined by the sulphur content of reactive minerals contained in flotation tailings or mining wastes [71] and it is enhanced by the presence of Thiobacillus ferrooxidan bacteria [66]. AMD results from natural oxidation of sulphides or pyrite-rich tailings [65, 66, 70], with a generation of sulphuric acid based on the weathering reactions shown in Table 5 [69].

Table 5: Oxidation paths of sulfide minerals

\begin{tabular}{|c|c|}
\hline \multicolumn{2}{|r|}{ Oxygen Path } \\
\hline Pyrite & $\mathrm{FeS}_{2}+\mathrm{H}_{2} \mathrm{O}+7 / 2 \mathrm{O}_{2} \rightarrow \mathrm{Fe}^{2+}+2 \mathrm{SO}_{4}^{2-}+2 \mathrm{H}^{+}$ \\
\hline Chalcopyrite & $\mathrm{CuFeS}_{2}+2 \mathrm{O}_{2} \rightarrow \mathrm{Fe}^{2+}+\mathrm{Cu}^{2+}+2 \mathrm{SO}_{4}^{2-}$ \\
\hline Sphalerite & $\mathrm{ZnS}+2 \mathrm{O}_{2} \rightarrow \mathrm{Zn}^{2+}+\mathrm{SO}_{4}^{2-}$ \\
\hline Galena & $\mathrm{PbS}+2 \mathrm{O}_{2} \rightarrow \mathrm{Pb}^{2+}+\mathrm{SO}_{4}^{2-}$ \\
\hline Arsenopyrite & $\mathrm{FeAsS}+3.25 \mathrm{O}_{2}+1.5 \mathrm{H}_{2} \mathrm{O} \rightarrow \mathrm{Fe}^{2+}+\mathrm{HAsO}_{4}^{2-}+\mathrm{SO}_{4}^{2-}+2 \mathrm{H}^{+}$ \\
\hline \multicolumn{2}{|r|}{ Ferric iron path } \\
\hline Pyrite & $\mathrm{FeS}_{2}+14 \mathrm{Fe}^{3+}+8 \mathrm{H}_{2} \mathrm{O} \rightarrow 15 \mathrm{Fe}^{2+}+2 \mathrm{SO}_{4}^{2+}+16 \mathrm{H}^{+}$ \\
\hline Chalcopyrite & $\mathrm{CuFeS}_{2}+16 \mathrm{Fe}^{3+}+8 \mathrm{H}_{2} \mathrm{O} \rightarrow 17 \mathrm{Fe}^{2+}+\mathrm{Cu}^{2+}+2 \mathrm{SO}_{4}^{2-}+16 \mathrm{H}^{+}$ \\
\hline Sphalerite & $\mathrm{ZnS}+8 \mathrm{Fe}^{3+}+4 \mathrm{H}_{2} \mathrm{O} \rightarrow 8 \mathrm{Fe}^{2+}+\mathrm{Zn}^{2+}+\mathrm{SO}_{4}^{2-}+8 \mathrm{H}^{+}$ \\
\hline Galena & $\mathrm{PbS}+8 \mathrm{Fe}^{3+}+4 \mathrm{H}_{2} \mathrm{O} \rightarrow 8 \mathrm{Fe}^{2+}+\mathrm{Pb}^{2+}+\mathrm{SO}_{4}^{2-}+8 \mathrm{H}^{+}$ \\
\hline
\end{tabular}


These reactions are the sources of mineralogical and geochemical alterations of sulphide minerals leading to the sulphuric acid leaching of oxidation products, with the release of metal elements to the environment $[65,68$, 72]. The absence of neutralizing substances (Table 6) in sulphide-rich tailings promotes the establishment and spreading of an AMD [69].

Table 6: Compounds inducing chemical reaction involved in the consumption of acid

\begin{tabular}{|c|c|}
\hline Neutralizing Compound & Reaction Leading to the Consumption of Acid Generated During the Oxidation of Sulfides \\
\hline Calcite & $\mathrm{CaCO}_{3}+2 \mathrm{H}^{+} \rightarrow \mathrm{Ca}^{2+}+\mathrm{CO}_{2}+\mathrm{H}_{2} \mathrm{O}$ \\
\hline Chlorite & $\left(\mathrm{Mg}_{4.5} \mathrm{Fe}_{0.2}^{\mathrm{II}} \mathrm{Fe}_{0.2}^{\mathrm{III}} \mathrm{Al}\right) \mathrm{AlSi}_{3} \mathrm{O}_{10}(\mathrm{OH})_{8}+16 \mathrm{H}^{+} \rightarrow 4.5 \mathrm{Mg}^{2+}+0.2 \mathrm{Fe}^{3+}+2 \mathrm{Al}^{3+}+3 \mathrm{SiO}_{2}+12 \mathrm{H}_{2} \mathrm{O}$ \\
\hline Plagioclase & $\mathrm{Na}_{0.75} \mathrm{Ca}_{0.25} \mathrm{Al}_{1.25} \mathrm{Si}_{2.75} \mathrm{O}_{8}+5 \mathrm{H}^{+} \rightarrow 0.75 \mathrm{Na}^{+}+0.25 \mathrm{Ca}^{2+}+1.25 \mathrm{Al}^{3+}+2.75 \mathrm{SiO}_{2}+2.5 \mathrm{H}_{2} \mathrm{O}$ \\
\hline Potassium feldspar & $\mathrm{KalSi}_{3} \mathrm{O}_{8}+\mathrm{H}^{+}+4 \mathrm{H}_{2} \mathrm{O} \rightarrow \mathrm{K}^{+}+3 \mathrm{H}_{4} \mathrm{SiO}_{4}+\mathrm{Al}(\mathrm{OH})_{3}$ \\
\hline
\end{tabular}

Neutralizing substances, therefore, block the formation and spread of AMD via consumption of the acid generated due to the weathering of sulphide minerals. Neutralizing substances act through the increase in the $\mathrm{pH}$ causing the precipitation of metal elements contained in the water of which the quality has been affected by AMD, which process allows the containment of the pollution. This is the reason why the control of pH is very important before releasing to the environment wastewater from mining origin [73]. In the Cities of Kipushi and Kinsenda (DR Congo), where large amounts of sulphide tailings have been exposed to air and water since many years, the risk of AMD spreading is minimized given that the storage sites are located on dolomitic geological formations known as the Kakontwe limestone [56, 57, 74].

AMD is therefore a source of contaminated and aggressive waters (rich in sulphates and carbonates) that are emitted owing to its dissolving capacity enhanced by acidity and bacteria. Thus, it is a natural process capable of negatively impacting water quality in a variety of ways $[68,71]$. Indeed, AMD usually lowers the pH of water, resulting in increased mobility and the build-up of metal elements up to concentrations qualified as toxic toward any form of life (Table 7). Copper and arsenic concentrations observed, for instance, at Buck Creek (Ohio-USA) were 750 and 20 times higher than their ordinary values [71], with the water rendered unsuitable for any use [75].

Table 7: Water from an abandoned copper mine polluted by the AMD

\begin{tabular}{|c|c|c|c|c|c|c|}
\hline Parameter & $\mathbf{p H}$ & $\mathbf{F e}(\mathbf{m g} / \mathbf{L})$ & $\mathbf{S O}_{4}{ }^{2-}(\mathbf{m g} / \mathbf{L})$ & $\mathbf{C u}(\boldsymbol{\mu g} / \mathbf{L})$ & Zn $(\boldsymbol{\mu g} / \mathbf{L})$ & As $(\boldsymbol{\mu g} / \mathbf{L})$ \\
\hline \hline Value & 3,83 & 542 & 3642 & 1880 & 9599 & 108 \\
\hline
\end{tabular}

AMD had caused significant environmental damages such as the deforestation of large tracts of land and pollution of both surface and groundwater $[75,76]$.

\subsection{Mine Extraction Operations}

At the mining stage, water is used in drilling as a lubricant, in washing operations of mining equipment and in many other applications [59]. The excavations were done on a given mining site usually result in the release of highly mineralized waters containing lubricant oils due to leaks happening on mining machinery and equipment. Those waters contain also fine solid particles, large amounts of cations and anions such as sulphate and chloride ions. Nitrate and ammonium ions are also present in those waters type mainly as the outcome of mining operations. The best management of such mineralized waters is essential in order to prevent contamination of both ground water and surface one.

\subsection{Mineral Processing and Tailings Management}

Metallurgical processes release large amounts of acidic or alkaline-type polluted waters in which high concentrations of trace metals, cyanides, sulphates, etc. can be present. The ores flotation is an important source of polluted waters. Indeed, different reagents are utilized to separate useful minerals from the gangue. In parallel, 
the metal elements are liberated into the process water by the surface dissolution of minerals subjected to flotation. Unconsumed reagents, together with their degradation products, are also transferred to the wastewater generated due to the ores flotation [77].

The flotation of sulphide ores using xanthates as collectors together with the grinding and beneficiation of oxidized minerals of base metals through flotation, of course after their sulphidization, result in the formation of thiosalts in the process water $[78,79]$. The generation of thiosalts during the flotation of a sulphide ore, containing pyrite, for instance, takes place using the following chemical reactions' sequence:

$$
\begin{gathered}
\mathrm{FeS}_{2}+2 \mathrm{O}_{2}+\mathrm{H}_{2} \mathrm{O} \rightarrow \mathrm{Fe}^{2+}+2 \mathrm{OH}^{-}+2 \mathrm{~S}^{\circ} \\
4 \mathrm{~S}^{\circ}+6 \mathrm{OH}^{-} \rightarrow 2 \mathrm{~S}^{2-}+\mathrm{S}_{2} \mathrm{O}_{3}^{2-}+3 \mathrm{H}_{2} \mathrm{O} \\
3 \mathrm{~S}_{2} \mathrm{O}_{3}^{2-}+2 \mathrm{O}_{2}+\mathrm{H}_{2} \mathrm{O} \rightarrow 2 \mathrm{~S}_{3} \mathrm{O}_{6}^{2-}+2 \mathrm{OH}^{-} \\
4 \mathrm{~S}_{2} \mathrm{O}_{3}^{2-}+\mathrm{O}_{2}+2 \mathrm{H}_{2} \mathrm{O} \rightarrow 2 \mathrm{~S}_{4} \mathrm{O}_{6}^{2-}+4 \mathrm{OH}^{-}
\end{gathered}
$$

Thiosulphate ions generated by the grinding and beneficiation of ores through flotation are converted into polythionate ions and further on, into the sulphate ions as the oxidation process end-products (Figure 5). Thiosalts $\left(\mathrm{S}_{\mathrm{x}} \mathrm{O}_{\mathrm{y}}{ }^{-2}\right)$ is partially converted into sulphur-bearing more oxidized compounds considered as the products of sulphide minerals' alteration.

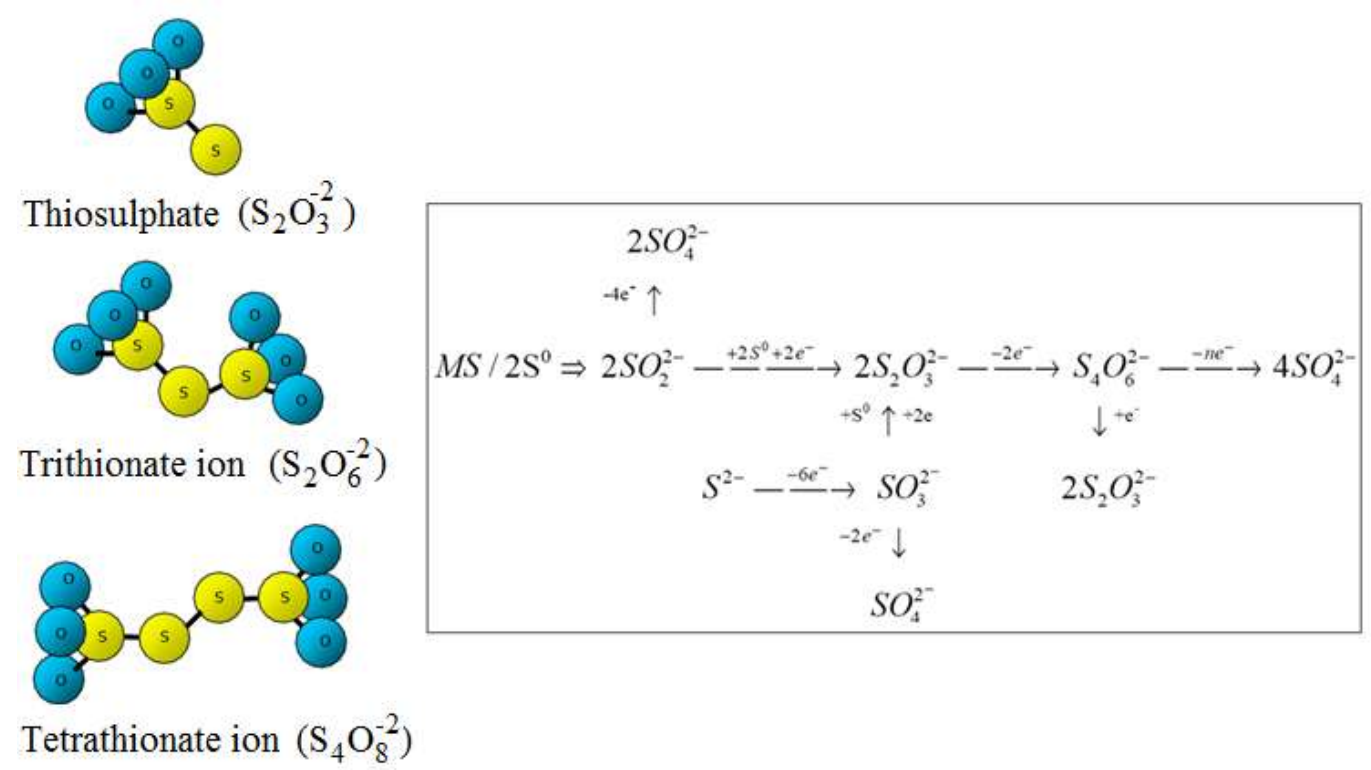

Figure 5: Thiosel generation during the flotation of sulphide ores (After [79]).

Apart from the unconsumed flotation reagents and metal elements of which the formation has been highlighted above, the wastewater from the flotation of either sulphide or oxidized minerals also contains the thiosalts generated due to oxidation of flotation reagents $\left(\mathrm{Na}_{2} \mathrm{~S}\right.$, NaHS and xanthates) by reaction with air introduced into the pulp. As can be seen from the reactions (5) to (7), the conversion of thiosulphate ions and polythionate ions into sulphate ion is bringing about the acidification of the process water. This process renders unsuitable water for recycling in ores flotation $[55,79,80]$ :

$$
\begin{aligned}
& \mathrm{S}_{2} \mathrm{O}_{3}^{2-}+2 \mathrm{O}_{2}+\mathrm{H}_{2} \mathrm{O} \rightarrow 2 \mathrm{SO}_{4}^{2-}+2 \mathrm{H}^{+} \\
& \mathrm{S}_{2} \mathrm{O}_{6}^{2-}+2 \mathrm{O}_{2}+2 \mathrm{H}_{2} \mathrm{O} \rightarrow 3 \mathrm{SO}_{4}^{2-}+4 \mathrm{H}^{+} \\
& \mathrm{S}_{4} \mathrm{O}_{6}^{2-}+\frac{7}{2} \mathrm{O}_{2}+3 \mathrm{H}_{2} \mathrm{O} \rightarrow 4 \mathrm{SO}_{4}^{2-}+6 \mathrm{H}^{+}
\end{aligned}
$$


In addition, the degradation kinetics of thiosalts, during the storage in tailings ponds of liquid effluents from ores flotation, is sometimes so slowed that some of them are not converted into sulphate ions [78]. Subsequent oxidation of thiosalts into sulphate ions, through bacteria-induced processes (Table 8), leads to the generation of acid in watercourses utilized as spillways for flotation wastewater [78, 79, 81].

Table 8: Bacteria involved in thiosalts oxidation

\begin{tabular}{|c|c|c|}
\hline Name & Substrates Utilized & pH \\
\hline \hline Thiobacillus thiooxidans & Sulphur, tetrathionate, thiosulphate. & $\begin{array}{c}\text { Optimum } 2.0-3.0 \\
\text { Range } 1.0-6.0\end{array}$ \\
\hline Thiobacillus thioparius & Sulphur, trithionate, Tetrathionate \\
& Dithionate, thiosulphate. & Optimum near neutrality \\
\hline Thiobacillus neapolatinus & Sulphur, thiosulphate. & Optimum 7.0 \\
& & Range $4.5-7.8$ \\
\hline Thiobacillus novellus & Thiosulphate, organics & Optimum 7.0 \\
& Range 5-9.5 \\
\hline Thiobacillus detrificans & Sulphur, Thiosulphate, Dithionate, & Range 6-8 \\
& Tetrathionate, sulphide. & \\
\hline
\end{tabular}

The bio-oxidation of thiosalts can therefore provide elemental sulphur, highly oxidized polythionates, or lead to sulphate ions formation, depending on the environment that prevails inside tailings ponds. Under well-controlled conditions, the final product from thiosalts oxidation is the sulphate ion as per the reaction chemical (7). The oxidation of thiosalts increases the dissolving capacity of water, a process capable of bringing about secondary pollution through the redissolution of metal elements initially trapped in waterway sediments. Liquid effluents from the ores flotation can thus endanger the flora, fauna and human health through the pollution of receiving media $[26,79]$.

\section{Treatment Technologies for Wastewaters of Mining and Metallurgy Origin}

\subsection{Physical Treatment}

This treatment utilizes several techniques adapted to the decontamination of different types of wastewater. A special focus is put on the description of techniques for the treatment of polluted water of mining origins.

\subsubsection{Water Treatment Using Membrane Technologies}

Membrane technologies are used in the treatment of water containing pollutants such as polycyclic aromatic hydrocarbons and other pollutants [10]. During the treatment of polluted waters, these technologies utilize mainly the size exclusion as a mean to remove pollutants apart from other mechanisms such as hydrophobic effects and adsorption on the membrane surface [10]. Membrane technologies comprise microfiltration, ultrafiltration, nanofiltration and reverse osmosis [10,82]. The latter is a technique $[37,63,83]$ used for water purification and based on membrane filtration under high pressure (2000 to $8000 \mathrm{k} \mathrm{Pa}$ ). Reverse osmosis, which accounts for more than 30 years in the production of drinking water, is now increasingly used in wastewater treatment [9, 84]. Indeed, with the strengthening of environmental regulation in both developed countries and developing ones, membrane filtration (Figure 6) has become since 1990 a more attractive option in the production of recyclable water from industrial wastewater $[1,9,37]$.

In Chile, reverse osmosis is utilized in the treatment of recyclable water in the copper industry [85]. It is also implemented in the treatment of water for the recharge of overexploited aquifers or wells threatened by drying up. However, reverse osmosis, as it is the case of other membrane technologies, remains a very expensive water treatment technique (€0.76-2.12/ $\mathrm{m}^{3} /$ year) owing to its high energy consumption and the scaling of nano-filters resulting in decreased performances over time $[6,10,37,86]$. This water treatment technology is thus accessible only in the world's wealthy regions, such as Israel, as well as Chile and Australia, which are areas very confronted 
with severe drought [9]. However, according to [21], treatment costs have significantly decreased over the last few decades owing to the progress achieved in terms of lower energy consumption, the use of enhanced materials for construction and improvement in the filter membranes' life [6]. Consequently, seawater desalination was quoted at around $\$ 0.64-0.80 / \mathrm{m}^{3}$ in the mid-1990s, for a large size plant, operated based on a membrane process, compared to the quotation around $\$ .50 / \mathrm{m} 3$ for large-reverse osmosis plants.

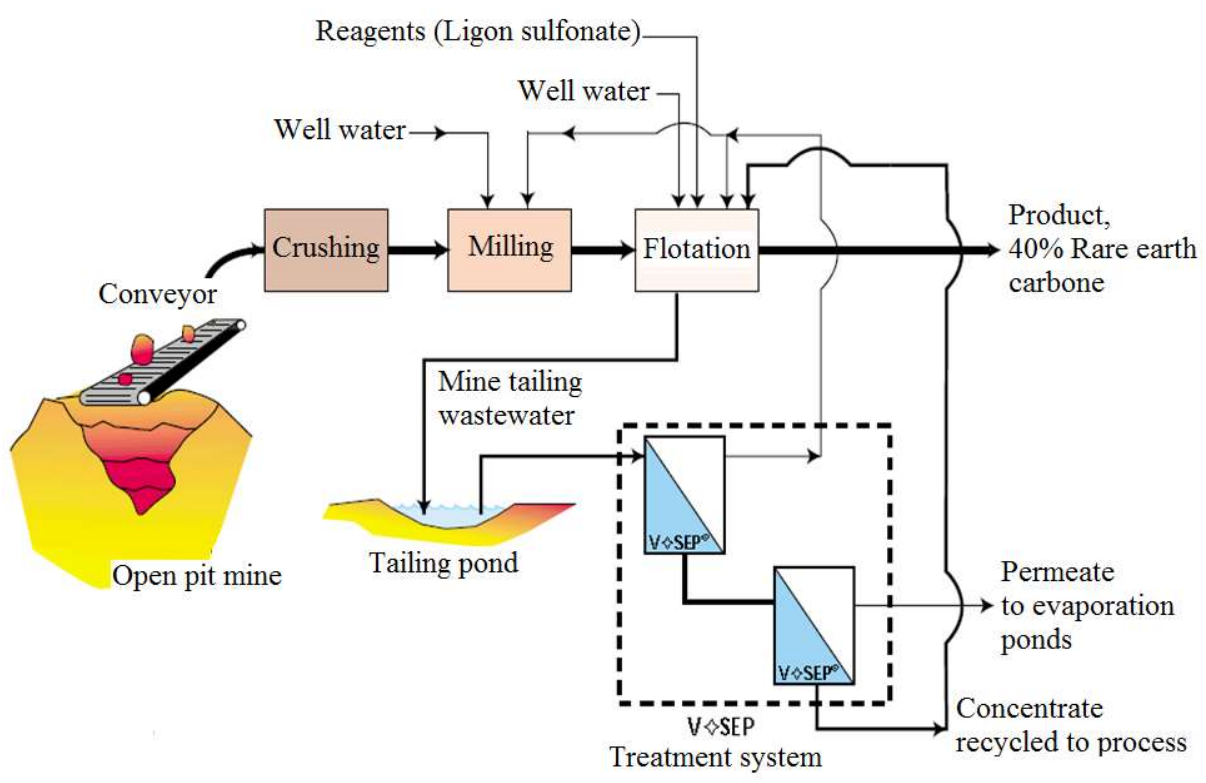

Figure 6: Water treated using membrane filtration and its recycling in ore flotation (after [37]).

Reverse osmosis utilizes nano-porous filter membranes $(0.2-1.0 \mathrm{~nm})$ and operates using dimensional exclusion or steric effect, electric charges, exclusion and solute-solvent-membrane physicochemical interactions to remove bacteria together with other pollutants present in the water as molecules and ions [6]. It is more effective than traditional techniques in removing bioorganic contaminants such as hormones and bioactive molecules of pharmaceuticals contained in wastewater emanating from households and biomedical centres [84].

Membrane technologies for wastewater reclamation have never been utilized in the Katanga province (DR Congo). They could play a leading role in the treatment of highly saline wastewater from the mining industry and thus help keep it under control and minimize adverse effects from the saltiness on aquatic wildlife of waterways utilized as spillways for industrial wastewater.

\subsubsection{Pollutants Removal Through Flotation}

Known as a mineral separation technique, flotation possesses interesting environmental applications as a method for treating industrial and household wastewater [24, 35, 87, 88]. In this area, it can be used in conventional mode as traditionally used in ores beneficiation [24] or as a dissolved air flotation (DAF) for treating wastewater (Table 9).

Table 9: Main differences conventional flotation and dissolved air flotation

\begin{tabular}{|l|l|}
\hline \multicolumn{1}{|c|}{ Conventional Flotation } & \multicolumn{1}{c|}{ Dissolved Air Flotation } \\
\hline \hline - Utilized in mineral ores beneficiation; & $-\quad$ Utilized for wastewater treatment; \\
- $\quad$ Solid-liquid separations (e.g., mineral and gangue); & $-\quad$ Solid-liquid or liquid-liquid separations (immiscible); \\
- $\quad$ Air dispersion in water (bulbs of $300-1500 \mu \mathrm{m}) ;$ & $-\quad$ Micro bulbs formation $(<100 \mu \mathrm{m}) ;$ \\
- $\quad \begin{array}{l}\text { Derive profit from the natural (talc, sulphides, coal, etc.) or } \\
\text { induced wetability (use of surfactants and modifying agents, } \\
\text { etc.) of minerals. }\end{array}$ & $-\quad \begin{array}{l}\text { Treatment of water contaminated by AMD and contaminants } \\
\text { particles and dispersions, metals ion, etc.). }\end{array}$ \\
\hline
\end{tabular}


[89] have conducted at the laboratory scale conventional flotation in the removal of oils contained in domestic wastewater. A residual concentration slightly below the threshold value $(50 \mathrm{mg} / \mathrm{L})$ was achieved using aluminium sulphate as a coagulating agent at a pH of 5.5. In parallel, [90] showed that the combination of conventional flotation with reverse osmosis filtration allows the economical removal of copper contained in wastewater. Besides, high removal yields of copper were achieved using optimal doses of sodium dodecyl sulphate and polyacrylamide as a surfactant and a flocculent, respectively. DAF is currently utilized in the treatment of different types of industrial and domestic wastewater [24]. It enables the removal from the water of metal ions, oils as well as fine dispersions, micro particles, etc. The hourly treatment capacity of a flotation unit with dissolved air can reach $20,000 \mathrm{~m}^{3}$ of liquid effluents [91]. DAF is an emerging and expensive water treatment technique, which has been widely used in the treatment of wastewater from the oil industry, in the ores flotation (Figure 7) and in the coal mine in Brazil.

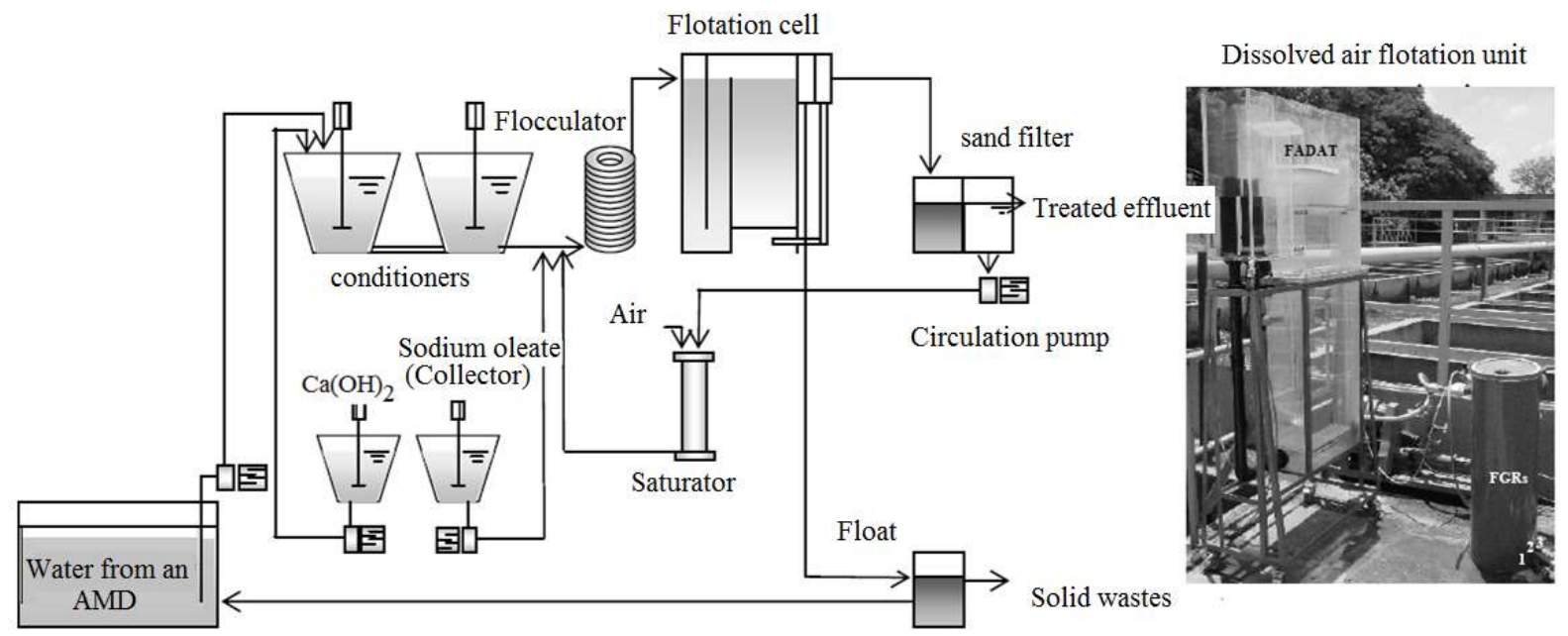

Figure 7: Decontamination of water polluted by an AMD using dissolved air flotation (After [38]).

In Katanga region (DR Congo), the Kakanda ores concentrator in view recycling wastewater from the flotation of copper-cobalt oxidized ores mined at the Mukondo deposit [92] had successfully utilized DAF in 2008. The widespread use of DAF in the treatment of wastewater from copper hydrometallurgical plants can help minimize the discharge of polluted waters into watercourses. It can also help produce both recyclable water intended for industrial processes and for less demanding applications from the quality standpoint and thus, promote the sustainable management of water resources in the Katanga region.

\subsection{Physicochemical Treatment}

Among conventional methods for treating inorganic waste waters such as discharges from the mining industry, adsorption $[46,93]$ has become one of the better treatment alternatives given that it can be implemented using various low-cost adsorbents and with larger metal-binding capacities [46, 94, 95]. Adsorption can be defined as is a simple, useful and effective water treatment method $[27,96]$ that is based on a mass transfer process enabling to bind to a solid phase (an adsorbent) substances contained in water via physical or chemical interactions [93, 96]. According to [27], adsorption is acknowledged as one of the major treatment methods applicable to the decontamination of water considering that it is technically simpler and economically feasible [93, 96, 97]. Indeed, it is implemented using various adsorbents consisting of materials of mineral, organic and biological origin [27, 94]. The adsorbents can also consist of materials such as activated carbon, zeolites, as well as cheaper materials such as by-products from industrial processes, agricultural wastes and biosorbents consisting of stems, bark, leaves, including old newspaper, etc. [46, 93-97]. [98] showed that adsorption is technically feasible to remove, with high efficiency (up to $92 \%$ of chromium), heavy metal from industrial wastewater using composite biosorbent prepared by coating chitosan onto acid-treated oil palm shell charcoal, that is, a product derived from natural materials [46, 93]. However, according to [96], who were interested in zinc removal from wastewater, using adsorbents derived from waste material, adsorption has the disadvantage of failing to remove heavy metals when present to low concentrations [46,93]. Moreover, its efficiency depends on the type of adsorbents used [96]. 
This wastewater treatment technique has never been used in the mining industry in Katanga region (DR Congo). However, tests carried out at the laboratory scale have proved the effectiveness of adsorption in the treatment of wastewater of industrial origin. For instance, liquid discharges (pH: 1.6; $86.99 \mathrm{mg} / \mathrm{L} \mathrm{Cu;} 24.85 \mathrm{~g} / \mathrm{L} \mathrm{Co}$ and $16.47 \mathrm{mg} / \mathrm{L} \mathrm{Mn}$ ) released by the Shituru hydrometallurgical process have been treated through adsorption (20 minutes) of metal elements using the powder $(1 \mathrm{~g})$ of the plant species Fiurena umbellatta (particle size equal to $214 \mu \mathrm{m}$ ). Adsorption with this biosorbent type has enabled removing $71 \%$ of the copper, $63 \%$ of the cobalt and $27 \%$ of the manganese initially present in wastewater subjected to treatment. [99]. Another example to be mentioned is the treatment through adsorption using activated charcoal (with the particle size equal to 210-250 $\mu \mathrm{m}$ ) of wastewater ( $\mathrm{pH}: 8.34 ; 8.41 \mathrm{mg} / \mathrm{L} \mathrm{Cu} ; 7.35 \mathrm{mg} / \mathrm{L}$. Co; $2.21 \mathrm{mg} / \mathrm{L} \mathrm{Mn}$ and $1.35 \mathrm{mg} / \mathrm{L} \mathrm{Fe}$ ) from the flotation of copper-cobalt ores. It enabled the removal of more than $99 \%$ of the majority of metal ions present in wastewater subjected to treatment [100]. Besides, the treatment through adsorption (10 minutes) of wastewater ( $\mathrm{pH}: 1.65$; $86.99 \mathrm{mg} / \mathrm{L} \mathrm{Cu} ; 24.85 \mathrm{mg} / \mathrm{L} \mathrm{Co}$ and $22.57 \mathrm{mg} / \mathrm{L} \mathrm{Mn}$ ) from the Shituru Hydrometallurgical process, enabled removing $95 \%$ of the copper, $80 \%$ of the manganese and $70 \%$ of the cobalt. In this case, a biosorbent made of the biomass $(0.5 \mathrm{~g}$ with the particle size of $202 \mu \mathrm{m})$ of the plant species Juissaea abyssinica was utilized [101].

\subsection{Chemical Treatment}

Chemical treatment of industrial liquid effluents in respect of environmental requirements is a common practice, worldwide [102]. Chemical treatment is an old method widely used for water polluted by an AMD [50, 103-106]. This water treatment method is based on the precipitation of dissolved contaminants by means of chemical reagents $\left(\mathrm{CaO}, \mathrm{Ca}(\mathrm{OH})_{2}, \mathrm{Na}_{2} \mathrm{CO}_{3}, \mathrm{Mg}(\mathrm{OH})_{2}, \mathrm{NaHS}, \mathrm{Na}_{2} \mathrm{~S}\right.$, etc.), with the neutralization of its acidity [36]. Thus, chemical reagents destabilize dissolved or suspended contaminants in water by neutralizing their charges, forming bonds between particles to induce sedimentation [36, 103]. A chemical reagent can be used alone or mixed with a coagulant to increase treatment efficiency [103]. Some illustrations of the chemical treatment of wastewater are given below:

\subsubsection{Neutralization with Lime}

This technique is used in the treatment of wastewater from mining origin. It can both correct the $\mathrm{pH}$ of acidic waters and precipitate their pollutants (Table 10). According to [94], precipitation using lime is one of the most effective treatment means for inorganic liquid effluents of which metals concentration exceeds $1000 \mathrm{mg} / \mathrm{L}$.

Lime is the most commonly used neutralizing agent (Table 10) in the treatment of polluted water. [107] have conducted at the laboratory scale the chemical treatment, using lime, of wastewater from the flotation of ores conducted at the Kipushi Concentrator (DR Congo). They have succeeded to rid wastewater of metal elements (Table 11).

Unlike other neutralizing reagents, lime is less expensive and provides heavy sludge with small volumes and without the possibility of remobilization of precipitated metal elements [103]. Its major drawback is the production of sludge with high pollution capacity. From the economic perspective and as with all precipitating agents, the reagents and sludge management's cost can be a major obstacle to the treatment of large volumes of wastewater using lime [50, 102]. That is the reason why the processes leading to high-density sludges are more preferred for rendering easy their management [44]. The treatment by lime of wastewater is a common practice at hydrometallurgical plants in Katanga region [57]. At the laboratory scale, there are numerous examples of the chemical treatment of industrial wastewater $(\mathrm{pH}: 7.82 ; 5.7 \mathrm{mg} / \mathrm{L} \mathrm{Co} ; 3.0 \mathrm{mg} / \mathrm{L} \mathrm{Mn} ; 118 \mathrm{mg} / \mathrm{L} \mathrm{Ca} ; 26 \mathrm{mg} / \mathrm{L} \mathrm{Mg} ; 0.2$ $\mathrm{mg} / \mathrm{L} \mathrm{Fe} ; 0.2 \mathrm{mg} / \mathrm{L} \mathrm{Ni} ; 1.8 \mathrm{mg} / \mathrm{L} \mathrm{Cu}$ and $0.2 \mathrm{mg} / \mathrm{L} \mathrm{Pb}$ ) from the Katanga region (DR Congo) such as wastewater from the flotation of oxidized copper and cobalt ores. Among those examples, one can retain the treatment of wastewater from the ores flotation conducted at Kipushi through precipitation of metal elements using sodium carbonate $(1.5 \mathrm{~g} / \mathrm{L})$ solution [108]. It had significantly enabled reducing the concentrations of cobalt $(99.2 \%)$, manganese (92.3\%), calcium (76.4\%) and magnesium (88.2\%). This same treatment had enabled reduction by half $(50.0 \%)$ the concentrations of iron and nickel with the elimination of more than half (57.1\%) of the copper and a quarter of the lead (25.2\%) present in the wastewater [108]. 
Table 10: Lime neutralization of mine water and copper flotation liquid effluents in the USA

\begin{tabular}{|c|c|c|c|c|c|c|c|c|}
\hline \multirow{2}{*}{ Sample } & \multirow{2}{*}{ Treatment pH } & \multicolumn{7}{|c|}{ Total Metal Concentrations (mg/L) } \\
\hline & & Fe & $\mathrm{Cu}$ & Zn & $\mathbf{P b}$ & Cd & As & Hg \\
\hline \multirow{6}{*}{$\begin{array}{l}\text { Mine water \& } \\
\text { mill tailings }\end{array}$} & 6.5 & 0.35 & 1.09 & 22.8 & 0.01 & 0.32 & 0.006 & 0.0006 \\
\hline & 7.0 & 0.06 & 0.33 & 5.4 & $<0.01$ & 0.18 & 0.009 & $<0.0005$ \\
\hline & 8.0 & 0.05 & 0.06 & 0.29 & $<0.01$ & 0.04 & 0.002 & $<0.0005$ \\
\hline & 9.0 & 0.05 & 0.04 & 0.09 & 0.01 & 0.02 & 0.004 & $<0.0005$ \\
\hline & 10.0 & 0.05 & 0.05 & 0.06 & 0.01 & 0.01 & 0.004 & $<0.0005$ \\
\hline & 11.0 & 0.10 & 0.04 & 0.04 & $<0.01$ & 0.01 & 0.006 & 0.0008 \\
\hline \multirow[t]{2}{*}{ Mill Tailings (Control) } & - & 0.06 & 0.09 & 0.06 & 0.01 & 0.01 & 0.003 & $<0.0005$ \\
\hline & & \multicolumn{7}{|c|}{ Dissolved Metal Concentrations (mg/L) } \\
\hline \multirow{6}{*}{$\begin{array}{l}\text { Mine water \& } \\
\text { mill tailings }\end{array}$} & 6.5 & 0.06 & 1.00 & 22.1 & $<0.01$ & 0.31 & - & - \\
\hline & 7.0 & 0.03 & 0.26 & 5.4 & $<0.01$ & 0.18 & - & - \\
\hline & 8.0 & 0.02 & 0.06 & 0.29 & $<0.01$ & 0.04 & - & - \\
\hline & 9.0 & 0.02 & 0.04 & 0.09 & $<0.01$ & 0.02 & - & - \\
\hline & 10.0 & 0.02 & 0.05 & 0.06 & $<0.01$ & 0.01 & - & - \\
\hline & 11.0 & 0.02 & 0.03 & 0.04 & $<0.01$ & 0.01 & - & - \\
\hline Mill tailings (control) & - & 0.01 & 0.04 & 0.06 & $<0.01$ & $<0.01$ & - & - \\
\hline
\end{tabular}

*Mine water: 5 parts; Mill tailings: 9 parts.

Table 11: Precipitation agents used in the treatment of polluted water

\begin{tabular}{|c|c|c|c|c|}
\hline Product & $\begin{array}{c}\text { Lime (Calcium Oxide or } \\
\text { Hydroxide) }\end{array}$ & $\begin{array}{l}\text { Soda Ash (Sodium } \\
\text { Carbonate) }\end{array}$ & $\begin{array}{c}\text { Caustic Soda (Sodium } \\
\text { Hydroxide) }\end{array}$ & Magnesium Hydroxide \\
\hline Form of material & $\begin{array}{c}\text { Solid - } \mathrm{CaO} \\
\text { Powder - } \mathrm{Ca}(\mathrm{OH})_{2} \\
\text { Slurry 35\% - } \mathrm{Ca}(\mathrm{OH})_{2}\end{array}$ & $\begin{array}{c}\text { Power }-\mathrm{Na}_{2} \mathrm{CO}_{3} \\
\text { Solution } 15 \%-\mathrm{Na}_{2} \mathrm{CO}_{3}\end{array}$ & Solution $50 \%-\mathrm{NaOH}$ & Slurry $58 \%$ - $\mathrm{Mg}(\mathrm{OH})_{2}$ \\
\hline $\begin{array}{l}\text { Alkali requirement } \\
\text { per ton } \mathrm{H}_{2} \mathrm{SO}_{4} \\
\text { per ton } \mathrm{HCl}\end{array}$ & $\begin{array}{l}\text { As CaO: } \\
1,240 \text { lbs. } \\
1,670 \text { lbs. }\end{array}$ & $\begin{array}{l}2,190 \mathrm{lbs} . \\
2,900 \mathrm{lbs} .\end{array}$ & $\begin{array}{l}1,630 \mathrm{lbs} . \\
2,160 \mathrm{lbs} .\end{array}$ & $\begin{array}{l}1,190 \mathrm{lbs} . \\
1,600 \mathrm{lbs} .\end{array}$ \\
\hline $\begin{array}{l}\text { Cost per ton of } \\
\text { neutralizing agent } \\
\text { (on a dry basis) }\end{array}$ & $\begin{array}{c}\mathrm{CaO}-\$ 60 \\
\mathrm{Ca}(\mathrm{OH})_{2}-\$ 80 \\
\text { Slurry } \mathrm{Ca}(\mathrm{OH})_{2}-\$ 100 \\
\text { Cost stable }\end{array}$ & $\begin{array}{l}\mathrm{Na}_{2} \mathrm{CO}_{3}-\$ 80 \\
\text { Cost variable }\end{array}$ & $\begin{array}{c}\mathrm{NaOH}-\$ 280 \\
\text { Cost highly variable }\end{array}$ & $\begin{array}{l}\mathrm{Mg}(\mathrm{OH})_{2}-\$ 300 \\
\text { Cost increasing }\end{array}$ \\
\hline $\begin{array}{l}\text { Cost to neutralize } 1 \\
\text { ton of } \mathrm{H}_{2} \mathrm{SO}_{4}\end{array}$ & $\begin{array}{c}\mathrm{CaO}-\$ 37 \\
\mathrm{Ca}(\mathrm{OH})_{2}-\$ 82\end{array}$ & $\mathrm{Na}_{2} \mathrm{CO}_{3}-\$ 86$ & $\mathrm{NaOH}-\$ 228$ & $\mathrm{Mg}(\mathrm{OH})_{2}-\$ 179$ \\
\hline Maximum pH at $25^{\circ} \mathrm{C}$ & 12.45 & $>11$ & 14 & 10.6 \\
\hline Sludge profile & $\begin{array}{l}\text { Heavy, low volume but } \\
\text { easy handling even if } \\
\text { heavy metals present }\end{array}$ & $\begin{array}{c}\text { High volume, gel-like } \\
\text { when heavy metals } \\
\text { present }\end{array}$ & $\begin{array}{c}\text { High volume, gel-like } \\
\text { when heavy metals } \\
\text { present }\end{array}$ & Heavy, low volume \\
\hline Salts & $\begin{array}{l}\text { Insoluble calcium metal } \\
\text { Hydroxyl salts }\end{array}$ & Soluble sodium salts & Soluble sodium salts & $\begin{array}{l}\text { Soluble magnesium } \\
\text { Metal hydroxyl salts }\end{array}$ \\
\hline $\begin{array}{c}\text { TDS } \\
\text { (total dissolved solids) }\end{array}$ & Low & High & High & High \\
\hline Reaction time & $\begin{array}{l}\text { Moderately fast-acting to } \\
\text { complete neutralization }\end{array}$ & $\begin{array}{l}\text { Moderately fast-acting to } \\
\text { complete neutralization }\end{array}$ & $\begin{array}{l}\text { Extremely fast-acting to } \\
\text { complete neutralization }\end{array}$ & $\begin{array}{l}\text { Fairly slow-acting to } 95 \% \\
\text { complete neutralization }\end{array}$ \\
\hline
\end{tabular}




\subsubsection{Neutralization and Purification Using a Reactive Drain}

In this case, the chemical treatment is carried out via the passage of water inside a waterproofed underground trench constructed using a plastic film or a geomembrane. That underground trench was filled with grinded limestone, with the particle size comprised between $2-4 \mathrm{~cm}$ or $8-25 \mathrm{~cm}[44,109]$. It consists of a shallow (1-2 m) anoxic limestone-made drain (ALD) that is $0.6-1 \mathrm{~m}$ wide and a variable length of up to $20 \mathrm{~m}$ depending on the desired treatment degree and the flow rate of the water to be treated (Figure 8 ).

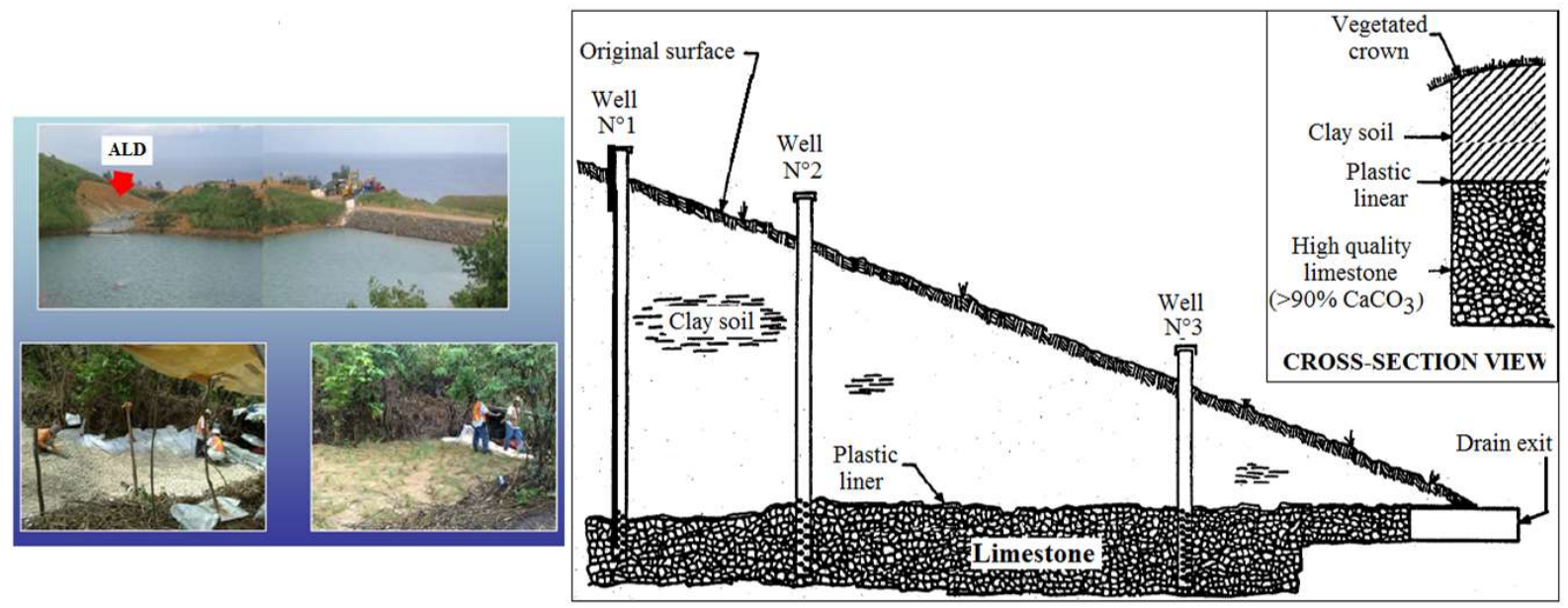

Figure 8: Treatment of AMD water using a limestone anoxic drain (ALD) (modified from [109]).

ALDs have water retention times ranging from 14 to 23 hours and are most commonly used for treating acidic wastewater containing metal elements and particularly those generated by AMDs [44, 109]. The treatment is based on the addition to water of calcium and bicarbonate ions through the dissolution of a high-grade limestone (82-99\% $\mathrm{CaCO}_{3}$ and $\left.0.4-4.5 \% \mathrm{MgCO}_{3}\right)$. This process brings about the increase in the $\mathrm{pH}$ of the water and the precipitation of metal elements. Around the neutrality $(\mathrm{pH}=7)$, the removal of metal ions occurs through oxidation and hydrolysis, with precipitation happening downstream of the anoxic drain. That is why ALDs are always working in combination with wetlands in order to push further the treatment through oxidation and precipitation of iron including other water contaminant [44]. Anoxic environment that prevails inside the drain enables preventing limestone grains from undergoing passivation through the formation of a hydroxides layer. The same environment also prevents the water circulation channels from being obstructed [109]. The ALD performs passive, efficient and inexpensive treatment of wastewater [44] in spite of the fact that the process requires regular monitoring in view an efficient functioning.

For optimal water depollution using ALDs, the concentrations of dissolved oxygen, as well as those of iron and aluminium ions, must remain below $1 \mathrm{mg} / \mathrm{L}$. As for the sulphate ion, its concentration must be less than 2000 $\mathrm{mg} / \mathrm{L}$. For low acidic or neutral polluted water [44], open limestone drains (OLD) are used to neutralize or buffer wastewaters before they pass through an aerated pond where the metal elements ( $\mathrm{Fe}, \mathrm{Cu}, \mathrm{Al}, \mathrm{Zn}$, etc.) are removed through oxidation and precipitation. Despite the advantages that this treatment technique can offer in terms of the elimination of acidity and metal ions present in wastewater from mining sources, it has not yet been used in the Katanga region where cases of water and soil pollution by acidic muds have been recently experienced.

\subsubsection{Precipitation of MTE Using Sulphide and Hydrogen Sulphide Ions}

This wastewater treatment method utilizes the sulphides $\left[\mathrm{Na}_{2} \mathrm{~S},\left(\mathrm{NH}_{4}\right)_{2} \mathrm{~S}, \mathrm{NaHS}, \mathrm{FeS}, \mathrm{BaS}\right.$ or $\left.\mathrm{H}_{2} \mathrm{~S}\right]$ as precipitating reagents of pollutants [44]. It has the advantage of producing sludge (precipitates) of base metal sulphides, which are less soluble than their hydroxides. Water pollution being usually more intense, the resulting sludge is chemically more stable or less reactive, due to a change in $\mathrm{pH}$, when stored under anaerobic conditions [44]. Precipitation of metal elements using sodium sulphide is used in the treatment of wastewater from the flotation of Cu-Zn ores [104]. Given that the treatment is based on the neutralization of wastewater with lime, it also 
produces highly polluting sludges. This treatment is used to clean up mining origin waters. It has been successfully implemented at the Raglan mine in Canada (Figure 9).

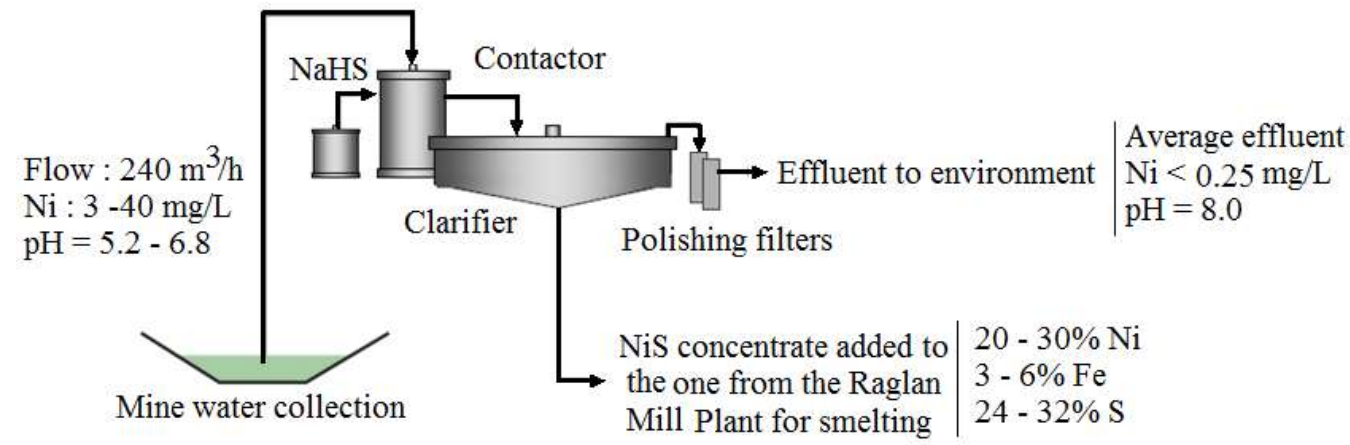

Figure 9: Precipitation of metals ions by means hydrogen sulphide ions (modified from [110]).

This treatment has the particularity of providing clean water of environmental quality as well as sludges that are rich in recoverable nickel sulphides [110]. However, the treatment units release harmful $\mathrm{H}_{2} \mathrm{~S}$ and produce colloidal precipitates difficult to separate from the treated water by means of ordinary filtration techniques. This renders very expensive the removal of pollutants from wastewater through precipitation of metal ions as sulphides comparatively to their removal as hydroxides in the presence of lime. Consequently, the treatment is not widely utilized in the clean-up of industrial wastewaters except in a few rare cases [44]. This type of water treatment has not yet been used at an industrial scale in the Katanga region (DR Congo). However, treatment tests conducted at the laboratory-scale on wastewater $(\mathrm{pH}: 8.04 ; 8.1 \mathrm{mg} / \mathrm{L} \mathrm{Mn} ; 0.2 \mathrm{mg} / \mathrm{L} \mathrm{Ni} ; 16 \mathrm{mg} / \mathrm{L} \mathrm{Mg} ; 1.4 \mathrm{mg} / \mathrm{L} \mathrm{Cu}$ and $11.9 \mathrm{mg} / \mathrm{L} \mathrm{Co}$ ) from the flotation of copper and cobalt ores, using sodium sulphide as precipitating reagent, enabled successfully precipitating major metal elements [108]. Indeed, virtually all of the manganese $(100,0 \%)$, much of the nickel $(95,1 \%)$ and magnesium $(98,2 \%)$ as well as more than half of the copper $(57.4 \%)$ and cobalt (60.4\%) initially present in wastewater were removed [108].

\subsection{Biological Treatment}

Biological treatment utilizes a passive process to clean up water [44, 102]. Although very demanding from the point of view of the implementation, it is more economical and environmentally friendly [26]. It does not generate contaminants and relies on the use of natural biological materials and processes. In the processing of mineral ores, biological treatment is used for ridding mining origin wastewater of pollutants for their safe discharge in watercourses or their recycling [22, 102]. The implementation of the biological treatment of wastewater is exemplified below.

\subsubsection{Pollutants Digestion and Removal Using Biogenic Sulphides}

The decontamination of polluted waters of mining origin is done using natural biodegradation or bacterialstimulated processes [36]. A supply of nutrients or of sources of energy [102] such as lactates, pyruvates, formiates, malates, acetates and organic and inorganic pollutants themselves promotes the growth and breeding of bacteria involved in the pollutant removal processes. For illustrative purposes, Bacillus polymyxa was utilized in the biodegradation of surfactants $\left[\left(\mathrm{CH}_{3}\right)_{2} \mathrm{CHOCS}_{2} \mathrm{Na}, \mathrm{CH}_{3}\left(\mathrm{CH}_{2}\right)_{11} \mathrm{OSO}_{3} \mathrm{NH}_{4}, \mathrm{CH}_{3}\left(\mathrm{CH}_{2}\right)_{7} \mathrm{CH}=\mathrm{CH}\left(\mathrm{CH}_{2}\right)_{7} \mathrm{COOH}\right.$, etc.] used also as reagents in ores flotation [76, 110]. Desulfovibrio and desulfotomaculum have been used in the clean-up of polluted waters from AMDs through precipitation of metal elements using biogenic sulphides [102]. At Nickel Rim (Sudbury), the biological treatment was implemented using a Permeable Reactive Barrier (PRB) that enabled, removing iron ( $>30 \%)$ together with sulphate ions from water contaminated by an AMD [102]. A sulphate-reductive barrier (SRB) has been used by the Calliope Mine (Montana) in view of the removal of zinc (99\%) from the water that has been in contact with acidogenic mining tailings $[36,102]$. This passive method is presently considered the most promising alternative to traditional methods owing to its high treatment efficiency, low operating cost and strong reproducibility [68]. 
At Leviathan mine (California-USA), biological treatment of mining water (Table 12) has been conducted using a bioreactor inside which a bacterial reduction of sulphates has been implemented for metal elements precipitation as sulphides [112].

Table 12: Treatment of polluted water with sulphate reducing bacteria

\begin{tabular}{|c|c|c|c|c|}
\hline \multirow{2}{*}{$\frac{\text { Parameter }}{\mathrm{pH}}$} & \multicolumn{4}{|c|}{ Treatment Duration } \\
\hline & 4.78 & 6.97 & 4.7 & 6.45 \\
\hline Temperature $\left({ }^{\circ} \mathrm{C}\right)$ & 9.9 & 15.6 & 8.4 & 13.1 \\
\hline Alkalinity (mg/L) & - & 1.458 & - & 269 \\
\hline $\mathrm{Al}(\mathrm{mg} / \mathrm{L})$ & 41.0 & 0.02 & 48 & 0.24 \\
\hline As (mg/L) & 0.41 & 0.023 & 0.28 & 0.015 \\
\hline $\mathrm{Fe}(\mathrm{mg} / \mathrm{L})$ & 310 & 2.8 & 380 & 260 \\
\hline $\mathrm{Ni}(\mathrm{mg} / \mathrm{L})$ & 1.8 & 0.01 & 2.1 & 0.01 \\
\hline Sulphate ion (mg/L) & 1,690 & 1,190 & 2,070 & 1,910 \\
\hline
\end{tabular}

\subsubsection{Depollution of Water Using a Wetland}

This passive technique for treating polluted water is based on biogeochemical reactions that occur in a natural aquatic environment $[34,44,109,113]$. Wetlands are used in the treatment of industrial and domestic wastewater $[114,115]$. They act as natural filtration media wherein take place biogeochemical processes [113-115] that are involved in the removal of pollutants (Figure 10).
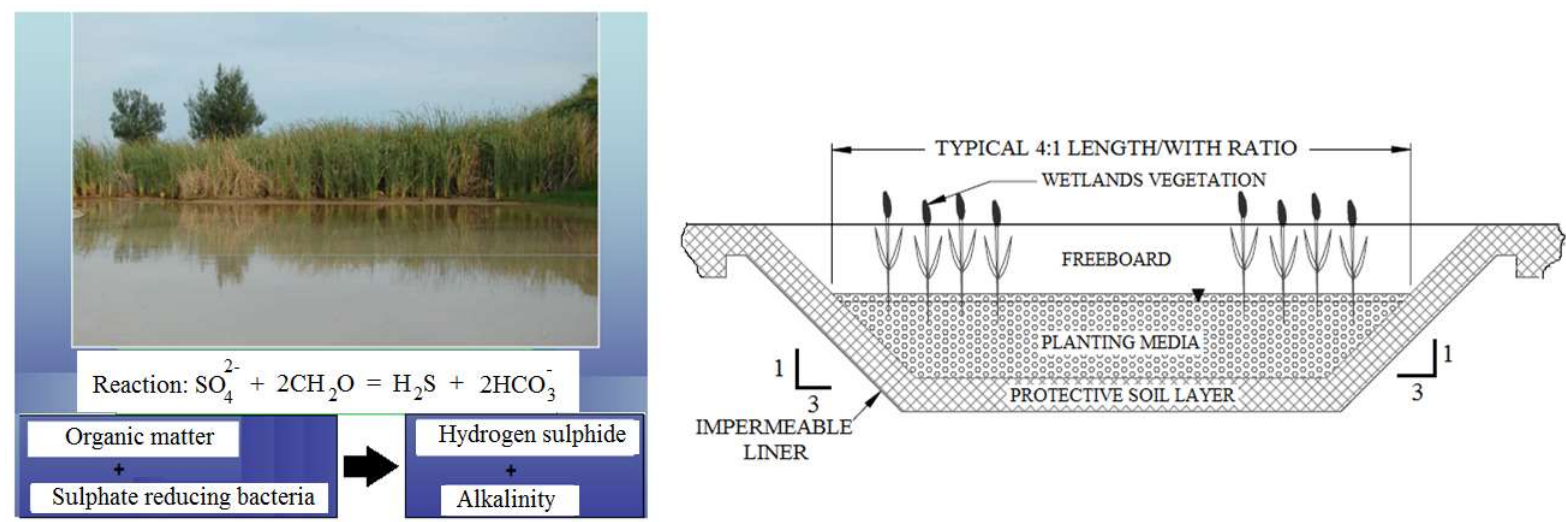

Figure 10: Depollution of water from an AMD using a wetland (modified from [34].

Wetlands are usually swamps, shallow lakes, coastal areas, etc. Sometimes, they consist of areas flooded naturally or artificially by water with a certain frequency. Their emergent vegetation is most often made up of plant species such as Typha latifolia, Phragmites australis, Eichhornia crassipes and other macrophytes [26, 113, 115120]. Wetlands constitute transitional ecological systems between land and the aquatic environment wherein the level of the water table is at or near the surface of the soil $[121,118,119]$.

Wetlands operate on the principle of phytobioremediation [26, 44, 122]. They consist of complex ecological systems where various chemical, physical and biochemical processes take place $[114,115]$ with a significant influence on water quality [109, 123, 124]. Wetlands are thus highly complex habitats where the interaction of biotic and abiotic factors results in a mechanical and biogeochemical filtration capable of removing pollutants from water [26, 115, 120]. The pollutant removal processes [26] and biogeochemical conditions that support their establishment in a wetland are described in Table 13 [34, 113]. 
Table 13: Biogeochemical processes for removing pollutants in a wetland

\begin{tabular}{|c|c|c|c|c|}
\hline \multirow{2}{*}{$\begin{array}{l}\text { Treatment } \\
\text { Processes }\end{array}$} & \multirow{2}{*}{$\begin{array}{l}\text { Biochemical Conditions in } \\
\text { Constructed Wetlands }\end{array}$} & \multicolumn{2}{|c|}{ Constructed Wetlands Components } & \multirow{2}{*}{$\begin{array}{c}\text { Examples of } \\
\text { Constituents' Removal }\end{array}$} \\
\hline & & Hydro Soil & Plants & \\
\hline \multicolumn{5}{|l|}{ Transfers } \\
\hline Sorption & $\begin{array}{c}\text { Availability and generation of } \\
\text { surfaces }\end{array}$ & $\begin{array}{l}\text { Law ratio of sand to clay; } \\
\text { High organic matter } \\
\text { content; porous }\end{array}$ & $\begin{array}{l}\text { Large mass of } \\
\text { roots and shoots }\end{array}$ & $\begin{array}{l}\text { Hydrophobic chemicals } \\
\text { (e.g., oil, grease, some } \\
\text { pesticides, } \\
\text { organometallics). }\end{array}$ \\
\hline Volatilization & $\begin{array}{c}\text { Presence of surface water and } \\
\text { transpiration }\end{array}$ & $\begin{array}{l}\text { Exposure to atmosphere } \\
\text { (e.g., during drawdown) }\end{array}$ & $\begin{array}{l}\text { Plants with } \\
\text { transpiration rates }\end{array}$ & $\begin{array}{l}\text { Chemical with high vapour } \\
\text { pressure or low solubility; } \\
\text { low-molecular-weight } \\
\text { organics }\end{array}$ \\
\hline $\begin{array}{l}\text { Precipitation, } \\
\text { settling and } \\
\text { sedimentation }\end{array}$ & $\begin{array}{l}\text { Flow rate less than } \\
\text { approximately } 10 \mathrm{~cm} / \mathrm{s} \\
\text { conducive to settling } \\
\text { (stokes law) }\end{array}$ & Not applicable & $\begin{array}{c}\text { Flow baffles to maintain } \\
\text { flow rate and prevent } \\
\text { short-circuiting }\end{array}$ & Solids and precipitates \\
\hline $\begin{array}{l}\text { Bioconcentration } \\
\text { (plant uptake) }\end{array}$ & $\begin{array}{c}\text { Prolific vegetation contact with } \\
\text { the water }\end{array}$ & $\begin{array}{c}\text { Favourable particle size } \\
\text { and nutrients to support } \\
\text { vegetative growth }\end{array}$ & $\begin{array}{l}\text { Large mass in contact } \\
\text { with water }\end{array}$ & $\begin{array}{l}\text { Hydrophobic chemicals } \\
\text { (e.g., oil, grease, some } \\
\text { pesticides, } \\
\text { organometallics) }\end{array}$ \\
\hline \multicolumn{5}{|l|}{ Transformations } \\
\hline Photolysis & $\begin{array}{l}\text { Sunlight intensity and light } \\
\text { absorption }\end{array}$ & Not applicable & Minimize shading & $\begin{array}{c}\text { low solubility; low- } \\
\text { molecular-weight organics }\end{array}$ \\
\hline Hydrolysis & $\begin{array}{l}\text { Acid, basic or neutral } \\
\text { environment depending on } \\
\text { targeted constituents }\end{array}$ & Not applicable & Not applicable & Pesticides \\
\hline $\begin{array}{l}\text { Speciation and } \\
\text { ionization }\end{array}$ & $\begin{array}{c}\text { Presence of reactive ions or } \\
\text { electrons (e.g., oxidation, } \\
\text { reduction) }\end{array}$ & $\begin{array}{l}\text { Refer to oxidation and } \\
\text { reduction (below) }\end{array}$ & $\begin{array}{l}\text { Refer to oxidation and } \\
\text { reduction (below) }\end{array}$ & Metals and organics \\
\hline Oxidation & $\begin{array}{l}\text { Redox (Eh) }>-50 \\
\text { (approximately); } \mathrm{pH} \text { slightly } \\
\text { acidic to near neutral }\end{array}$ & $\begin{array}{l}\text { High rate of sand to clay; } \\
\text { Low organic matter } \\
\text { content }\end{array}$ & $\begin{array}{l}\text { Rhizosphere aeration; } \\
\text { large radial oxygen loss }\end{array}$ & $\begin{array}{c}\text { Organics (e.g., oil and } \\
\text { grease); some metals (e.g., } \\
\text { Fe) }\end{array}$ \\
\hline Reduction & $\begin{array}{c}\text { Redox (Eh)<-150 } \\
\text { (approximately) pH near } \\
\text { neutral to slightly basic }\end{array}$ & $\begin{array}{l}\text { Low rate of sand to } \\
\text { clay; High organic } \\
\text { matter content }\end{array}$ & $\begin{array}{l}\text { small radial oxygen loss; } \\
\text { root metabolism in } \\
\text { anaerobic environment }\end{array}$ & $\begin{array}{l}\text { Metals (e.g., } \mathrm{Hg}, \mathrm{Cu}, \mathrm{Pb} \text {, } \\
\mathrm{Zn} \text { ); organochloride } \\
\text { chemicals subjected to } \\
\text { dehalogenation }\end{array}$ \\
\hline $\begin{array}{l}\text { Biotransformation } \\
\text { and biodegradation }\end{array}$ & $\begin{array}{l}\text { Presence of organisms and } \\
\text { enzymes capable of } \\
\text { transforming targeted } \\
\text { constituents }\end{array}$ & $\begin{array}{c}\text { Favourable particle size } \\
\text { and nutrients to support } \\
\text { microbial growth }\end{array}$ & $\begin{array}{c}\text { Plant to support } \\
\text { periphytic and } \\
\text { Rhizosphere microbial } \\
\text { growth }\end{array}$ & Biodegradable organics \\
\hline
\end{tabular}

The environment that prevails inside a wetland [34, 117] dictates the establishment and the extent of biogeochemical processes implicated in the depollution of water, including oxidation, reduction, chelation, adsorption, complexation, sedimentation, filtration, biosorption of pollutants by plants and their microbial digestion. The hydrological regime, geology and sediment chemistry, the composition of the microbial community, fauna and flora, and the geomorphology and position of the wetland in a given landscape [121] influence this environment. Thus, in a wetland, oxidizing conditions prevail on the water surface up to the water-sediment interface [115] and this is not the case in the depth of the sediments where reducing (anaerobic) conditions predominate $[113,115]$. The bacteria (sulphate-reducing species, denitrifying species, etc.) that live in wetlands catalyse the retention reactions of metal elements [44,119]. As for metal elements present in solution found in the oxidation zone, they are eliminated through biosorption by macrophytes, which constitute a natural filter 
wherein oxidation processes take place $[44,117]$. Metal elements are also removed through chelation or via the organic complexation reactions [123].

In the anaerobic zone of a wetland, bacteria reduce sulphates to hydrogen sulphide through the oxidation of organic matter [44]. Metal ions $\left(\mathrm{Zn}^{2+}, \mathrm{Pb}^{2+}, \mathrm{Cu}^{2+}\right.$, and other metal ions) are retained by precipitation (insoluble compounds) as the outcome of their reaction with hydrogen sulphide (Figure 10). For a system that has already reached its sorption limit, the most dominant metals removal mechanism becomes sulphide formation [123].

In a wetland, an anoxic or reducing environment results from microbial or animal respiration together with the slowed diffusion of oxygen into water and deep sediments [119]. Depending on the nature of the pollutants targeted, it is, therefore, possible to promote the establishment of an oxidative or reducing process, that is to say, the maintenance in a wetland of aerobic or anaerobic conditions that favour a given reactional process [109].

Since 1950, wetlands have been utilized successfully in the treatment of nutrient-rich runoff intended for agricultural use $[113,115]$. They are presently utilized in the treatment of contaminated waters from the industrial origin, polluted and acidic water generated by AMDs, municipal wastewater and petroleum refining wastewater, including organic and inorganic wastewater from landfills or those generated due to leaching of solid tailings of the mining and metallurgical processing of ores [34,44,109, 113-115, 120,123,124]. Wetlands are also utilized to control the water runoff pollution in urban areas, including the pollution of storm-generated runoff $[113,117,121$, 122].

In Canada, the decontamination of AMDs water had been conducted using passive treatment techniques such as ALDs, biosorption-based systems and wetlands [109, 114]. Indeed, in a wetland, the contaminated water from AMDs can flow by gravity and undergo both depollution and neutralization, respectively, via the reactions of precipitation, chelation and ionic exchange as well as via the action of the sulphate-reducing bacteria [114].

Currently, wetland performance (Table 14) makes them more attractive in terms of efficiency and cost compared to traditional wastewater treatment techniques such as lime neutralization, the process based on activated sludge or percolation filtration $[115,117-120,123]$.

Table 14: Treatment of AMDs from coal mines using wetlands in England

\begin{tabular}{|c|c|c|c|c|c|}
\hline Wetland & $\begin{array}{l}\text { Mine Water Total } \\
\text { Iron Loading (kg/day) }\end{array}$ & $\begin{array}{l}\text { Outlet Total Iron } \\
\text { Loading (kg/day) }\end{array}$ & $\begin{array}{c}\text { Removal Rate } \\
(\%)\end{array}$ & $\begin{array}{l}\text { Removal Rate } \\
\left(\mathrm{g} / \text { day } / \mathrm{m}^{2}\right)\end{array}$ & $\begin{array}{c}\text { Acidity }\left(\mathrm{As} \text { Free } \mathrm{CO}_{2}\right) \\
\text { Removal Rate }\left(\mathrm{g} / \mathrm{day} / \mathrm{m}^{2}\right)\end{array}$ \\
\hline A & 9.3 & 1.5 & 83.2 & 8.1 & 9.5 \\
\hline B & 52.8 & 2.6 & 95.3 & 7.9 & 15.4 \\
\hline C & 38.8 & 1.1 & 96.0 & 5.8 & 9.3 \\
\hline
\end{tabular}

In addition, a wetland is more suitable for the treatment of large volumes of polluted water [34, 118]. A relevant illustration of this passive technique is given by the treatment of mining waters and wastewater generated by the flotation of Pb-Zn ores in the Philippines. Thus, there are several benefits to derive from the use of wetlands in the treatment of polluted water $[117,123,124]$. These include, but are not limited to the following:

- simpler construction with local materials and at low cost;

- adaptability to the quantity rather than to the quality of the water to be treated;

- stable operation based on natural processes for pollutant removal;

- easy implementation and maintenance;

- great treatment efficiency and affordability.

Concerning mining wastewaters, the combination of other treatment techniques such as adsorption or a system using a limestone trench in combination with constructed wetlands [44] has proven successful in the 
removal of heavy metals. Indeed, [125] have succeeded in achieving the removal of heavy metals (As-80.3\%, Mn96.9\%, Cd-79.6\%, Zn-52.9\% and $\mathrm{Pb}-38.7 \%)$ contained in mining wastewater after four months of treatment. The wastewaters were emanating from a $\mathrm{Pb}-\mathrm{Zn}$ mine located in northern Vietnam, with a constant flow rate of $5 \mathrm{~m}^{3} / \mathrm{day}$, and have been treated by adsorption. Modified iron-ore drainage sludge, in combination with a horizontal-subsurface-flow constructed wetland made with common reed (Phragmites australis) was utilized for wastewater treatment. Interested in improving the management of liquid effluents from the copper ore flotation in the Katanga region (DR Congo), [36] have considered the possibility of treatment of wastewater by biological techniques. They have suggested utilizing a wetland as a polishing stage after ridding wastewater of pollutants through treatment inside a tailings pond converted into a bioreactor.

\section{Conclusion}

Water plays a very essential role in human life and in the prosperity of all industries. However, water is an unevenly distributed resource on planet Earth. The water crisis includes the increasing deterioration in its quality and its ever-growing demand in the face of limited access to the resources available in the world. Accordingly, the development of water reuse, wastewater treatment processes and remediation systems has gained importance in view of increasing access to water. Different technologies, based on the utilization of physical, chemical, physicochemical and biological processes either alone or in combination with others in view to rid the wastewaters of pollutants, are utilised in the treatment of raw water and wastewaters of different origins, including those of the mining industry. They enable recovering water that can be reused either in other sectors or safely released to watercourses. It is important to keep in mind that each treatment technology has both advantages and disadvantages on efficiency, the implementation and maintenance cost, the operational time and technique as well as space requirements. These different criteria, together with others not addressed in the present work, are used to determine which treatment technique can be selected for the treatment of wastewater of mining origin.

\section{Acknowledgements}

We gratefully thank our probationers for heaving gathered data utilized during the writing of the present paper namely Epemel Mukudi, Bilianga Kanyere, Mumba Ozena and Maloba Nasson.

\section{Funding body}

None.

\section{Declaration of conflicts of interests}

The authors state that there no conflicts of interests.

\section{References}

[1] Al-Amshawee S, Bin Mohd Yunus MY, Mohd Azoddein AA, Geraint Hassell D, Habib Dakhil I, Abu Hasane H. Electrodialysis desalination for water and wastewater: A review, Chemical Engineering Journal 2020; 380: 122231. https://doi.org/10.1016/j.cej.2019.122231.

[2] Barker R, van Koppen B, Shah T. A global perspective on water scarcity and poverty: Achievements and challenges for water resources management. Colombo, Sri Lanka: International Water Management Institute (IWMI), $2000 . \quad$ Accessible via https://publications.iwmi.org/pdf/H026191.pdf

[3] Biswas AK. New Insights on Water Security in Asia, in Achieving water security for Asia, Asian Water Outlook Development 2007, ABD Water for all, Asia-Pacific Water Forum, Asian Development Bank, ISBN 978-981-4136-06-8.

[4] Basheer A, Attiq-ur-Rehman, Samiullah, Khan N, Hayatullah, Baqi A. Physico-chemical and heavy metals analysis of drinking water and their effect on human health: A Review. Pure and Applied Biology 2019; 9(1): 587-594. http://dx.doi.org/10.19045/bspab.2020.90064.

[5] Dubey RS, Bhardwaj S. Water Pollution and Its Treatment by Various Methods: A Review, Chemical Science Review and Letters 2020; 9 (34): 546-551. DOI:10.37273/chesci.CS205101105.

[6] Ezugbe EO, Rathilal S. Membrane Technologies in Wastewater Treatment: A Review, Membranes 2020;10 (89): 1-28. doi:10.3390/membranes10050089. 
[7] Hein C. Mager T, Ertsen M, Nijhuis S, Verschuure-Stuip G. Introduction: Connecting Water and Heritage for the Future, In Hein C. (ed): Adaptive Strategies for Water Heritage: Past, Present and Future 2020, Springer Nature Switzerland AG. https://doi.org/10.1007/978-3030-00268-8_1

[8] Homaeigohar S. The nanosized dye adsorbents for water treatment, Nanomaterials 2020; 10 (295): 1-43. doi:10.3390/nano10020295.

[9] Tota-Maharaj K, Hills CD. Water reclamation from Brackish Water using Reverse Osmosis (RO) Membrane Technologies in Southeast England, United Kingdom, Institute of Water Journal Aston University 2020; 5: 38-48.

[10] Adeola AO, Forbes PBC. Advances in water treatment technologies for removal of polycyclic aromatic hydrocarbons: Existing concepts, emerging trends, and future prospects, Water Environment Research 2020: 1-17.

[11] Shuning Dong, Bin Xu, Shangxian Yin, Yong Han, Xiaodong Zhang, Zhenxue Dai. Water Resources Utilization and protection in the Coal Mining Area of Northern China, Scientific Reports 2019; 9(1214): 1-10. Accessible via https://doi.org/10.1038/s41598-018-38148-4

[12] Brantes AR, Olivares G. Best practices and efficient use of water in the mining industry, Under the directorate of Zúñiga, A. I., The Chilean Copper Commission (COCHILCO), A Quebecor World printing, 2008, p. $11 . \quad$ Acessible via https://www.cochilco.cl/Research/best_practices_and_the_efficient_use_of_water.pdf.

[13] Caporali S, Mindreau L, Maza R, Solís ET, Sanguinetti ST, Miyashiro M. Water, each drop counts: let's use it wisely, the inter-american water day held at Lima (Peru) on October the $7^{\text {th }}, 2000$, The working guide on water: PAHO, WHO, AIDIS, CWWA, pp. 1-38.

[14] El Kharraz J, El-Sadek A, Noreddine Ghaffour N, Mino E, Water scarcity and drought in WANA countries, Procedia Engineering 2012; 33: $14-29$.

[15] New South Wales Minerals Council. Water in NSW minerals industry, Factsheet-Minerals: part of your life every minute, every day, Sydney, 2007, pp. 1-2.

[16] Naik PK. Water crisis in Africa: myth or reality?, International Journal of Water Resources Development 2016. http://dx.doi.org/10.1080/07900627.2016.1188266.

[17] Assaf K, Attia B, Darwish A, Wardam B, Klawitter S. Water as a human right: The understanding of water in the Arab countries of the Middle East - A four country analysis, Global Issue Papers №11, The Heinrich Böll Foundation publication, Berlin, 2004, pp. 1-268.

[18] Corcoran E, Nellemann C, Baker E, Bos R, Osborn D, Savelli H (eds). Sick Water? The central role of wastewater management in sustainable development, A Rapid Response Assessment, United Nations Environment Programme, UN-HABITAT, GRID-Arendal. www.grida.no, Printed by Birkeland Trykkeri AS, Norway, 2010, pp. 5-82.

[19] Bridges G. Country paper - India, Asian Water Forum, The Asian Water Development Outlook publication commissioned by the Asian Development Bank, 2007, pp. 1-21. Accessible via: https://www.aciwrm.org/wp-content/uploads/2019/09/awdo-2007.pdf

[20] Vannevel R, Goethals PLM. Identifying Ecosystem Key Factors to Support Sustainable Water Management, Sustainability 2020 ; 12 (1148): 1-23. doi:10.3390/su12031148

[21] Bhojwani S, Topolski K, Mukherjee R, Sengupta D, El-Halwagi MM. Technology review and data analysis for cost assessment of water treatment systems, Science of the Total Environment 2019; 651: 2749-2761.

[22] Alkherraz AM, Ali AK, Elsherif KM. Removal of $\mathrm{Pb}(\mathrm{II}), \mathrm{Zn}(\mathrm{II}), \mathrm{Cu}(\mathrm{II})$ and $\mathrm{Cd}(\mathrm{II})$ from aqueous solutions by adsorption onto olive branches activated carbon: Equilibrium and thermodynamic studies, Chemistry International 2020; 6(1): 11-20.

[23] Straatsma M, Droogers P, Hunink J, Berendrecht W, Buitink J, Buytaert W, Karssenberg, D, Schmitz O, Sutanudjaja EH, Van Beek (Rens) LPH, Vitolo C, Bierkens MFP. Global to regional scale evaluation of adaptation measures to reduce the future water gap, Environmental Modelling and Software 2020; 124: 104578. https://doi.org/10.1016/j.envsoft.2019.104578.

[24] Taşdemir T, Başaran HK. Floatability of Suspended Particles from Wastewater of Natural Stone Processing by Floc-Flotation in Mechanical Cell, El-Cezerî Journal of Science and Engineering 2020;7(2): 358-370. DOI: 10.31202/ecjse.644348.

[25] Ting Ma, Siao Sun, Guangtao Fu, Jim W. Hall, Yong Ni, Lihuan He, Jiawei Yi, Na Zhao, Yunyan Du, Tao Pei, Weiming Cheng, Ci Song, Chuanglin Fang, Chenghu Zhou. Pollution exacerbates China's water scarcity and its regional inequality, Nature Communications 2020; 11(650): 1-9. https://doi.org/10.1038/s41467-020-14532-5.

[26] Oyewumi Tolulope O, Ajayi Omoyemi O. Biological Treatment of Heavy Metal in Aquatic Environment: A Review of Wetland Phytoremediation and Plant-Based Biosorption Methods, International Journal of Current Research in Applied Chemistry \& Chemical Engineering 2020; 4(1): 46-52.

[27] Crini G, Lichtfouse E, Wilson L, Morin-Crini N. Conventional and non-conventional adsorbents for wastewater treatment. Environmental Chemistry Letters 2019; 17 (1): 195-213.

[28] Dobson RS, Burgess JE. Biological treatment of precious metal refinery waste water: A review, Minerals Engineering 2007; $20: 519-532$.

[29] Kostadinov L, Micevska O, Krstev B, Golomeov B, Golomeova M. Engineering for waste water treatment from tailing dumps, Proceedings of the XV Balkan Mineral Processing Congress, Sozopol, Bulgaria, June 12 - 16, 2013, pp. 1030-1032.

[30] Lin W, Dai Y, Wu C, Xu P, Ren J, Sun S, Li B. Continuous treatment of flotation collector wastewater using a membrane bioreactor, Water Science and Technology 2016; 73.8: 1901-1909.

[31] Moore BA. Investigation into the technical feasibility of biological treatment of precious metal refining wastewater, a thesis submitted in fulfilment of the requirements for the degree of doctor of philosophy, water resource science, The Institute of Water Research, Faculty of Science, Rhodes University, 2012, pp.1-141. 
[32] N'gandu D. The effect of underground mine water on performance of the Mufulira flotation process, Journal of the Southern African Institute of Mining and Metallurgy 2001; 101:367-380.

[33] Rao SR, Finch JA. Review of water re-use in flotation, Minerals Engineering 1989; 2: 65-85.

[34] Rodgers JH, Castle JW. Constructed wetland systems for efficient and effective treatment of contaminated waters for reuse, Environmental Geosciences 2008; 15(1): 1-8.

[35] Rubio J, Carissimi E, Rosa J. Flotation in water and waste-water treatment and reuse: recent trends in Brazil, International Journal of Environment and Pollution 2007; 30: 193-207.

[36] Shengo LM, Mutiti WNC. Bio-treatment and water reuse as feasible treatment approaches for improving wastewater management during flotation of copper ores, International Journal of Environmental Sciences and Technology 2016; 13: 2505-2520.

[37] Vigneswaran S, Ngo HH, Chaudhary DS, Hung Y-T. Physicochemical treatment processes for water reuse, in Wang, L. K., Hung, Y.-T. \& Shammas, N.K. (Eds.)., 2007. Handbook of Environmental Engineering, Volume 3: Physicochemical Treatment Processes, The Humana Press Inc., Totowa, NJ, 2007, pp. 635-676.

[38] Wilinski P, Naumczyk J. Dissolved Ozone Flotation as an innovative and prospect method for treatment of micropollutants and wastewater treatment costs reduction. $12^{\text {th }}$ edition of the World Wide Workshop for Young Environmental Scientists (WWW-YES-2012) Urban waters: resource or risks?, May 2012, Arcueil, France. hal-00709736.

[39] Yuan Z, Sun Sh, Bi J. Approaching Zero-discharge with Cleaner Production: Case Study of a Sulfide Mine Flotation Plant in China, International Journal of Environmental Restoration 2010;4(4): 759-764.

[40] WWAP. L'eau pour les hommes, l'eau pour la vie, Rapport mondial sur la mise en valeur des ressources en eau, UNESCO, Dep.Eau-02, Éditions UNESCO, 7, place de Fontenoy, 75352 Paris, 2003, pp. 1-31.

[41] Pöyry Consulting Co. Ltd. Market study on the business opportunities in municipal and industrial wastewater/ effluent treatment in China, General Report, December, the $18^{\text {th }}, 2009$, Beijing, pp.1-87.

[42] Missouri Department of Natural Resources. Preventing pollution in wastewater systems, Environmental Assistance Office, Jefferson City, 2002, pp.1-38.

[43] Woodrow TW. Practical Solutions for Optimizing Steel Mill Wastewater Treatment Plants, AISE Steel Technology, 2001, pp.46-48.

[44] Kuyucak N. Selecting suitable methods for treating mining effluents, Report prepared for the "PerCan Mine Closure" course, Lima (Peru), July 13-26, 2006, pp.1-34.

[45] Ermolenko A, Vikulova M, Shevelev A, Mastalygina E, Ogbuna Offor P, Konyukhov, Y, Razinov A, Gorokhovsky A, Burmistrov I. Sorbent Based on Polyvinyl Butyral and Potassium Polytitanate for Purifying Wastewater from Heavy Metal lons, Processes 2020; 8(690): 1-12. doi:10.3390/pr8060690.

[46] Ossman ME, Mansour MS. Removal of Cd (II) ion from wastewater by adsorption on treated old newspaper: Kinetics modelling and isotherm studies, International Journal of Industrial Chemistry 2013; 4(13): 2-7. http://www.industchem.com/content/4/1/13.

[47] Shukrullah S, Bashir W, UI Huda Altaf N, Khan Y, Al-Arainy AA, Sheikh TA. Catalytic and Non-Catalytic Treatment of Industrial Wastewater under the Exposure of Non-Thermal Plasma Jet, Processes 2020; 8(667): 1-15. doi:10.3390/pr8060667.

[48] Atmaca T, Kuyumcu HZ. Investigations on water consumption in mineral processing plants, Erzmetall 2003; 56(9): 558.

[49] Collins R, Kristensen P, Thyssen N. Water resources across Europe - confronting water scarcity and drought, EEA Report No. 2/2009, Copenhagen, 2009, pp.9-55. Accessible via:www.eea.europa.eu.

[50] Rulkens WH. Sustainable development in industry by closing cater loops: technological aspects and expected future developments, In: Mournighan, R. et al. (eds.), Chemistry for the Protection of the Environment 2007; 4: 223-253, Environmental Science Research 59, Springer.

[51] Slatter KA, Plint ND, Cole M, Dilsook V, De Vaux D, Palm N, Oostendorp B. Water management in Anglo Platinum process operations: effects of water quality on process operations. In: Abstracts of the international mine water conference organized by Cilla Taylor Conferences. 19th-23rd Oct 2009, Pretoria (South Africa), 2009, pp 46-55.

[52] New South Wales Minerals Council. Water use in the NSW minerals industry, Factsheet - Minerals: part of your life every minute, every day, Sydney, 2007, pp.1-2.

[53] Queensland Government. Industry water recycling background study, Prepared on behalf of Queensland Water Recycling Strategy by Kinhill Pty Ltd, Brisbane, 1999, pp.1-29.

[54] Singh M. Water consumption at copper mines in Arizona, Special report 29, Department of Mines \& Mineral Resources, State of Arizona, Phoenix, 2010, pp. 1-16.

[55] Levay G, Smart RStC, Skinner WM. The impact of water quality on flotation performance, Journal of Southern Africa Institute of Mining and Metallurgy, March/April 2001, pp.69-76.

[56] Countois Y, Maurice R, Arpin M, Demers B. Étude sur la restauration des mines de cuivre et de cobalt en République Démocratique du Congo, Rapport d'étude initiale N M-6708 (603082) des recherches en République Démocratique du Congo et rédigé par SNC-Lavalin International, Division Environnement, Montréal (Canada), 2003, pp.61-62, 163, $182 . \quad$ Accessible via: http://documents1.worldbank.org/curated/en/851161468243902395/pdf/E7390v120Env0Audit0Gecamines.pdf.

[57] Kalenga NM, Frenay J, Mukendi K, De Donato P, Kaniki TA. Inventory of sites of production, storage and disposal of mineral wastes in Katanga and assessment of their environmental impacts. A report related to a scientific project of cooperation (2005, No. 6312PS508) 
between the University of Lubumbashi (UNILU), the University of Liege (ULg) and the National Polytechnic Institute of Lorraine (INPL) funded by the French speaking countries Academic Agency, 2006, pp 1-217.

[58] Jennett J, Wixson B. Geochemistry, mining and the environment, Mineral Environment 2005; 5: 36-53

[59] Chadwick J. Water management: Minimizing water use and its pollution, International Mining, July 2007, pp.38-47.

[60] Álvarez LM. The socioeconomic impacts of the Bajo la Alumbrera project and an approach to the economic indicators of sustainability in Roberto Villas-Bôas, R. and Beinhoff, C. (Eds.): Indicators of sustainability for the mineral extraction industries, CYTED/MAA/UNIDO, Carajas, 2002, pp. 331-338.

[61] Lutandula MS, Kashala NG. Zinc oxide production through reprocessing of the electric arc furnace flue dusts, Journal of Environmental Chemical Engineering 2013; 1: 600-603.

[62] Davenport WG, King M, Schlesinger M, Biswas AK. Extractive metallurgy of copper, Fourth edition, Pergamon, The Netherlands, 2002, pp. 31-55.

[63] Frolova L, Shapa M, Butyrina T, Savchenko M, Hrydnieva T. Investigation of ultrasonic treatment of wastewater from iron compounds, E3S Web of Conferences 168, 00027, 2020, pp.1-7. https://doi.org/10.1051/e3sconf/202016800027.

[64] Nyrenda M. Impact from the (CMSK) wastewaters diversion upon the Kafubu river water quality. Project report Department of Chemistry, Faculty of Sciences, University of Lubumbashi, 2006, pp 16-21.

[65] Éthier M-P. Évaluation du comportement géochimique en conditions normale et froides de différents stériles présents sur le site de la mine raglan, a thesis in fulfilment of a Master degree in Applied Sciences (Mineral Processing), Department of Civil Engineering, Geology and Mines, École Polytechnique de Montréal, 2011, 204p.

[66] Kagambeg N, Sawadogo S, Bamba O, Zombre P, Galvez R. Acid mine drainage and heavy metals contamination of surface water and soil in southwest Burkina Faso-west Africa, International Journal of Multidisciplinary Academic Research 2014; 2 (3):9-19. Accessible via www.multidisciplinaryjournals.com.

[67] Oelofse S. Mine water pollution - Acid mine decant, Effluent and treatment: A consideration of key emerging issues that may impact the state of the environment, Emerging Issues Paper: Mine Water Pollution 2008, A document prepared for The South African Department of Environmental Affairs and Tourism (DEAT), 2008, pp. 1-11.

[68] Yanrong Dong, Junzhen Di, Xianjun Wang, Lindan Xue, Zhenhua Yang, Xuying Guo \&Mingwei Li. Dynamic Experimental Study on Treatment of Acid Mine Drainage by Bacteria Supported in Natural Minerals, Energies 2020; 13(439); 1-14. doi:10.3390/en13020439.

[69] Stoltz E. Phytostabilisation - use of wetland plants to treat mine tailings, Doctoral thesis, Department of Botany, Stockholm University, 2004, pp.1-45.

[70] Yilmaz E, Kesimal A, Erçikdi B. Evaluation of acid producing suphidic mine tailings as a paste backfill, Instanbul Üniv.Müh. Fak.Yerbilimberi Dergisi, C. 17, S. 1, 2004, pp. 11-19.

[71] Sumi L, Thomsen S. Mining in Remote Areas: Issues and impacts, Produced for MiningWatch Canada/Mines Alerte by the Environmental Mining Council of British Columbia, Printed by union labour at Fleming Printing, Victoria, BC, 2001, pp. 1-33.

[72] Wiertz JV, Marinkovic FA. Dissolved pollutant transport in tailings ponds, Environmental Geology 2005; 47: 237-240.

[73] Fosu S, Danuba EB, Krampah F, Joe-Asare T. A program in Visual Basic for Simulation and Control of Acidic Wastewater Neutralisation System", Ghana Journal of Technology 2020; 4 (2): 80 - 89.

[74] Kitobo SW. Dépollution et valorisation des rejets miniers sulfurés du Katanga, Cas des tailings de l'Ancien Concentrateur de Kipushi, Doctoral thesis in Engineering Sciences, Faculty of Applied Sciences, University de Liège, Belgium, 2009, pp.1-3, 38-218.

[75] Lintnerová O, Sottník P, Soltés S. Abandoned Smolník mine (Slovakia) - a catchment area affected by mining activities, Estonian Journal of Earth Sciences 2008; 57(2):104-110.

[76] State of Alaska and US EPA. Mining information session, Alaska Forum on the Environment held on February 12, 2008, Anchorage and Alaska, 2008, pp. 1-50.

[77] Chockalingam E, Subramanian S, Natarajan KA. Studies on biodegradation of organic flotation collectors using Bacillus polymyxa, Hydrometallurgy 2003: 71: 249-256.

[78] AQUAMIN. Évaluation des effets de l'exploitation minière sur le milieu aquatique au Canada, Document justificatif II: Synthèse régionale, Canada, 1996, pp.1-90.

[79] Kuyucak N, Yaschyshyn D. Managing thiosalts in mill effluents, Studies conducted at Kidd metallurgical site, International Conference on Mining and the Environment IV, Sudbury, 2007, pp.1-16.

[80] Australian Government Publishing Service Sodium Ethyl Xanthate, Priority Existing Chemical N5, Full Public Report, Canberra, 1995, pp.16-18, 21-24.

[81] Silver M. Parameters for the operation of bacterial thiosalt oxidation ponds, Applied and Environmental Microbiology 1985, 50 (3): 663 669.

[82] Simões A, Macêdo-Júnior R, Santos B, Silva L, Silva D, Ruzene D. Produced Water: An overview of treatment technologies, International Journal for Innovation Education and Research 2020; 8(4): 207-224. DOI: https://doi.org/10.31686/ijier.vol8.iss4.2283.

[83] Jennings GD, Sneed RE. Water quality and waste management glossary, Publication N EBAE 144-90, 1996, North Carolina Cooperative Extension Service. 
[84] Kunst B, Kosuti K. Removal of emerging contaminants in water treatment by nanofiltration and reverse osmosis, Hdb. Environmental Chemistry 2008; 5 (S/2): 103-125.

[85] Bosse MA, Schneider H, Cortina JL. Treatment and reutilization of liquid effluents of copper mining in desert zones, Water Sustainability and Integrated Water Resource Management, The Preliminary Program for 2007 Annual Meeting, 2007. Available from: http://aiche.confex.com/aiche/2007/preliminaryprogram/abstract_101082.htm.

[86] Fatta D, Kythreotou N. Water as valuable water resource- concerns, constraints and requirements related to reclamation, recycling and reuse, Proceedings of IWA International Conference on Water Economics, Statistics, and Finance, Rethymno, Greece, 2005, pp.8-10.

[87] Anastassakis G, Karageorgiou K, Paschalis M. Removal of phosphates species from solution by flotation, In: Gaballah, I. et al., (eds.), Proceedings of "REWAS 04": Global Symposium on Recycling and Clean technology, Vol. II, 26 September 2004, Spain, 2004, pp.11471154.

[88] Dibrov I, Voronin N, Klemyatov A. Froth flotoextraction - a new method of metal separation from aqueous solutions, International Journal of Minerals Processing 1998; 54: 45-58.

[89] Welz M, Baloyi N, Deglon D. Oil removal from industrial waste-water using flotation in a mechanically agitated flotation cell, Water S.A 2007; 33: 453-458

[90] Sudilovskiy P, Kagramanov G, Kolesnikov V. Use of RO and NF for treatment of copper containing waste-waters in combination with flotation, Desalination 2008; 221: 192-201.

[91] Cheremisinoff N. Biotechnology for waste and waste-waters treatment, Noyes Publications, Westwood, New Jersey, USA, 1996, pp.4244.

[92] Chadwick J. “CAMEC - the cobalt champion”, International Mining, July 2008, pp. 8-16.

[93] Al-Saydeh SA, El-Naas MH, Zaidi SJ. Copper removal from industrial wastewater: A comprehensive review, Journal of Industrial and Engineering Chemistry 2017; 56: 35-44.

[94] Barakat MA. New trends in removing heavy metals from industrial wastewater, Arabian Journal of Chemistry 2010; 4: $361-377$.

[95] Strugała-Wilczek A, Stańczyk K, Bebek K. Comparison of Metal Adsorption from Aqueous Solutions on Coal and Char Remaining After In-situ Underground Coal Gasifcation (UCG), Mine Water and the Environment 2020; 39: 369-379. https://doi.org/10.1007/s10230-02000677-8.

[96] Zwain HM, Vakili M, Dahlan I. Waste Material Adsorbents for Zinc Removal from Wastewater: A Comprehensive Review, International Journal of Chemical Engineering 2014; 1-13. http://dx.doi.org/10.1155/2014/347912.

[97] Montes-Atenas G, Valenzuela F. Wastewater treatment through low-cost adsorption technologies, in Physico-Chemical Wastewater Treatment and Resource Recovery, 2017, pp. 214-238. http://dx.doi.org/10.5772/67097.

[98] Nomanbhay SM, Palanisamy K. Removal of heavy metal from industrial wastewater using chitosan coated oil palm shell charcoal, Electronic Journal of Biotechnology 2005; 8(1): 43-53.http://www.ejbiotechnology.info/content/vol8/issue1/full/7/.

[99] Maloba N. Determination of the optimal conditions for the adsorption of mineral pollutants from the waste water of the hydrometallurgical plants of Shituru: Case of the use of powder of the plant species Fuirena umbellata as adsorbent of metals, a report on research initiated by the Department of Chemistry of the Faculty of Science of the University of Lubumbashi, Lubumbashi, 2010, pp. $1-32$.

[100] Bilianga K. Active Coal Adsorption Removal of Trace Metal Elements contained in Wastewater from Ore Flotation conducted at the New Concentrator in Kipushi, a report on research initiated by the Department of Chemistry of the Faculty of Science of the University of Lubumbashi, Lubumbashi, 2010, pp. 1-34.

[101] Mumba O. Clean-up of waste water at the Shituru hydrometallurgical plant by removing trace metal elements using the biomass of the plant species Juissaea abyssinica, a report on research initiated by the Department of Chemistry of the Faculty of Science of the University of Lubumbashi, Lubumbashi, 2010, pp. 1-42.

[102] Potvin R. Réduction de la toxicité des effluents des mines de métaux de base et précieux à l'aide de méthodes de traitement biologique, Rapport de synthèse environnementale, Université du Québec en Abitibi-Témiscaminque, Inédit, 2004, pp.7-20.

[103] EPA. Chemical precipitation, Wastewater Technology Fact Sheet, United States Environmental Protection Agency, Office of Water, Washington, D.C., 2000, pp.1-8. Accessible via : https://www.epa.gov/sites/production/files/2015-06/documents/package_plant.pdf

[104] Malkin V, Kuzin V. Purification of industrial waste waters using reagents, Chemical Petroleum Engineering 2001; 37: 338-343.

[105] Mulligan CN, Gibbs BF. Innovative biological treatment processes for wastewater in Canada. Water Quality Restoration Journal of Canada 2003;38: 243-265.

[106] Nedved M, Jansz J. Waste water pollution control in the Australian mining industry, Journal of Cleaner Production 2006; $14: 1118-1120$.

[107] Mukudi LE, Shengo LM. Improvement of methods used in the management of the process wastewater from flotation of copper-cobalt oxide ores at the new concentrator in Kipushi. An interim report of a research project carried out by the Chemistry Department, Faculty of Sciences. University of Lubumbashi, DRC, 2011, pp. 1-20.

[108] Ilunga MF. Determination of the optimum chemical treatment conditions for waste water from the flotation of oxidized copper and cobalt ores at the New Concentrator in Kipushi: Case of the treatment of water with sodium carbonate and sodium sulphide, a report on research initiated by the Department of Chemistry of the Faculty of Science of the University of Lubumbashi, Lubumbashi, 2010, pp. $1-37$. 
[109] Kilborn Inc. Review of passive systems for treatment of acid mine drainage, Phase II May 1996, Mend report 3.14.1 revised in 1999 and prepared for the Mine Environment Neutral Drainage (MEND) program; Toronto, 1999, pp. 1-79. Accessible via :http://mendnedem.org/wp-content/uploads/2013/01/3.14.1.pdf

[110] Bioteq Environmental Technologies Inc. Annual Report, 355 Burrard Street, Suite 1700, Vancouver, B.C., V6C 2G8, Canada, 2003, pp. 132. Document accessible sur le site web : www.bioteq.ca

[111] Namita D, Natarajan K. Biological removal of some flotation collector reagents from aqueous solutions and mineral surfaces, Mineral Engineering 1998; 11: 717-738

[112] Tsukamoto KT, Vasquez BF. Evolution of sulfate-reducing bioreactors, Ionic Water Technologies Co Communication, 2007, pp. 1-34.

[113] Opitz J, Alte M, Bauer M, Peifer S. The Role of Macrophytes in Constructed Surface-fow Wetlands for Mine Water Treatment: A Review, Mine Water and the Environment, 2021. https://doi.org/10.1007/s10230-021-00779-x.

[114] Pat-Espadas AM, Portales RL, Amabilis-Sosa LE, Gómez G, Vidal G. Review of Constructed Wetlands for Acid Mine Drainage Treatment, Water 2018; 10 (1685): 2-25. doi: 10.3390/w10111685.

[115] Skrzypiec K, Gajewska MH. The use of constructed wetlands for the treatment of industrial wastewater, Journal of Water and Land Development 2017; 34 (VII-IX): 233-240. DOI: 10.1515/jwld-2017-0058.

[116] Choudhary MP, Sharma S. Water Hyacinth - A complete solution to wastewater treatment, Reclamation and environmental protection, IE (I) Journal-EN89 2008: 52-54.

[117] Dhote S, Dixit S. Water quality improvement through macrophytes - a review, Environmental Monitoring and Assessment 2009; 152: 149-153.

[118] Kent DM (Eds). Applied wetlands science and technology, $2^{\text {nd }}$ edition, CRC Press LLC, Boca Raton, Florida, 2001, pp.451.

[119] Scholz M. Wetland systems to control urban runoff, $1^{\text {st }}$ edition, Elsevier, The Netherlands, 2006, pp. 91-110.

[120] Shardendu, Salhani, N, Boulyga SF, Stengel E. Phytoremediation of selenium by two helophyte species in subsurface flow constructed wetland, Chemosphere 2003; 50: 967-973.

[121] Sutula M, Stein E. Habitat value of natural and constructed wetlands used to treat urban runoff: a literature review, A report prepared for the California State Coastal Conservancy, The Southern California Coastal Water Research Project, 2003, pp. 2-19.

[122] EPA. A citizen's guide to phytoremediation, A Technology Fact Sheet from The Office of Solid Waste and Emergency Response, The Technology Innovation Office, The United States Environmental Protection Agency, 1998, pp. 1-6. Accessible via : https://cluin.org/download/remed/phyto2.pdf.

[123] Lorion R. Constructed wetlands: Passive systems for wastewater treatment, Technology status report prepared for the US EPA Technology Innovation Office under a National Network of Environmental Management Studies Fellowship, 2001, pp. 1-24.

[124] Shrestha KL. Decentralised wastewater management using constructed wetland in Nepal, Water aid in Nepal, Kupondole, 2008, pp.112.

[125] Nguyen HTA, Nguyen BQ, Duong TT, Bui ATK, Nguyen HTA, Cao HT, Mai NT, Nguyen KM, Pham TT, Kim K-W. Pilot-Scale Removal of Arsenic and Heavy Metals from Mining Wastewater Using Adsorption Combined with Constructed Wetland, Minerals 2019; 9(379): 1-15. doi:10.3390/min9060379. 